\title{
Thermal Conductivity and Sintering Behavior of Sm2Zr207 Ceramics with Y3+ Substitution for Different Lattices
}

\section{Zhaolu Xue}

Anhui University of Technology

\section{Xin Wang}

Anhui University of Technology

\section{Mengchuan Shi}

Anhui University of Technology

\section{Haiyuan Yu}

Beijing Beiye Functional Materials

\section{Xin Zhang}

BGRIMM: Beijing General Research Institute of Mining and Metallurgy

Shihong Zhang ( $\square$ tougaoyouxiang206@163.com )

Anhui University of Technology

\section{Research Article}

Keywords: Thermal barrier coating, Sm2Zr207, Y2O3 doping, Thermal conductivity, High-temperature sintering

Posted Date: June 11th, 2021

DOl: https://doi.org/10.21203/rs.3.rs-607252/v1

License: (9) This work is licensed under a Creative Commons Attribution 4.0 International License. Read Full License 


\title{
Thermal conductivity and sintering behavior of $\mathrm{Sm}_{2} \mathrm{Zr}_{2} \mathrm{O}_{7}$ ceramics with $\mathrm{Y}^{3+}$ substitution for different lattices
}

\author{
Zhaolu Xue ${ }^{\mathrm{a}}$, Xin Wang ${ }^{\mathrm{a}}$, Mengchuan Shi ${ }^{\mathrm{a}}$, Haiyuan $\mathrm{Yu}^{\mathrm{b}}$, Xin Zhang ${ }^{\mathrm{c}}$, Shihong Zhang ${ }^{\mathrm{a}, *}$
}

${ }^{a}$ Key Laboratory of Green Fabrication and Surface Technology of Advanced Metal Materials (Anhui University of Technology), Ministry of Education, Maanshan 243002, China

${ }^{\mathrm{b} B e i j i n g ~ B e i y e ~ F u n c t i o n a l ~ M a t e r i a l s ~ C o r p o r a t i o n, ~ B e i j i n g ~ 100192, ~ C h i n a ~}$

'BGRIMM Technology Group, Beijing 100160, China

* To whom all correspondence should be addressed. Tel \& fax: +86 5552315291.
E-mail address: tougaoyouxiang206@163.com

Abstract: $\operatorname{Sm}_{2} \mathrm{Zr}_{2} \mathrm{O}_{7}$ is one of the most promising candidate materials for ultra-high temperature thermal barrier coatings. In this paper, a series of $\left(\operatorname{Sm}_{1-x I} \mathrm{Y}_{x 1}\right)_{2}\left(\mathrm{Zr}_{1-x 2} \mathrm{Y}_{x 2}\right)_{2} \mathrm{O}_{7-x 2}$ ceramics with different lattice sites replaced by $\mathrm{Y}^{3+}$ ions were successfully prepared by the high-temperature solid-phase sintering method. The effect of $\mathrm{Y}^{3+}$ doping on microstructure, phase composition, thermal conductivity and sintering behavior of modified $\mathrm{Sm}_{2} \mathrm{Zr}_{2} \mathrm{O}_{7}$ ceramics were investigated, respectively. The results showed that $\left(\mathrm{Sm}_{1-x l} \mathrm{Y}_{x 1}\right)_{2}\left(\mathrm{Zr}_{1-x 2} \mathrm{Y}_{x 2}\right)_{2} \mathrm{O}_{7-x 2}$ were composed of a single pyrochlore crystal phase within $20 \% \mathrm{Y}^{3+}$ ions doping concentration. Compared with pure $\mathrm{Sm}_{2} \mathrm{Zr}_{2} \mathrm{O}_{7}$, the fracture toughness of each $\left(\mathrm{Sm}_{1-x l} \mathrm{Y}_{x 1}\right)_{2}\left(\mathrm{Zr}_{1-x 2} \mathrm{Y}_{x 2}\right)_{2} \mathrm{O}_{7-x 2}$ ceramic was significantly reduced. In terms of reducing the thermal conductivity of $\mathrm{Sm}_{2} \mathrm{Zr}_{2} \mathrm{O}_{7}$, the substitution of $\mathrm{Y}^{3+}$ ion for $\mathrm{Zr}^{4+}$ was more obvious than the substitution of $\mathrm{Y}^{3+}$ for $\mathrm{Sm}^{3+}$. Thermal conductivity of $\mathrm{Sm}_{2}\left(\mathrm{Zr}_{0.9} \mathrm{Y}_{0.1}\right)_{2} \mathrm{O}_{6.9}$ was $1.315 \mathrm{~W} \cdot \mathrm{m}^{-1} \cdot \mathrm{K}^{-1}$ at $1200{ }^{\circ} \mathrm{C}$, which was the lowest among the studied ceramics. $\mathrm{Sm}_{2}\left(\mathrm{Zr}_{0.9} \mathrm{Y}_{0.1}\right)_{2} \mathrm{O}_{6.9}$ ceramic exhibited a lower grain growth rate at $1400{ }^{\circ} \mathrm{C}$, and still remained a single pyrochlore crystal phase after sintering for $100 \mathrm{~h}$, indicating that $\left.\mathrm{Sm}_{2} \mathrm{Zr}_{0.9} \mathrm{Y}_{0.1}\right)_{2} \mathrm{O}_{6.9}$ had good high-temperature stability at $1400{ }^{\circ} \mathrm{C}$.

Key words: Thermal barrier coating; $\mathrm{Sm}_{2} \mathrm{Zr}_{2} \mathrm{O}_{7} ; \mathrm{Y}_{2} \mathrm{O}_{3}$ doping; Thermal conductivity; High-temperature sintering 


\section{Introduction}

With the continuous development of aero-engine technology, high thrust-to-weight ratio, high thermal efficiency, low fuel consumption and long service life of gas Turbine engine become the development trend in the future, while high thrust-to-weight ratio and thermal efficiency mean higher Turbine Inlet Temperature (TIT) [1, 2]. Engine combustion chamber and turbine blade and other hot end components are facing increasingly severe challenges due to the continuous increase of turbine inlet temperature [3]. At present, the nickel-based single crystal superalloy which is the main structural material of the hot end parts of aero engine has reached the temperature bearing limit. Therefore, besides gas film cooling technology, thermal barrier coatings (TBCs) technology can not only provide good thermal insulation protection for hot end parts, but also improve the thermal efficiency of the engine, and has become one of the core key technologies for hot end parts of advanced gas turbine engines $[4,5] .(6 \sim 8$, wt $\%) \mathrm{Y}_{2} \mathrm{O}_{3}$ partially stabilized $\mathrm{ZrO}_{2}(8 \mathrm{YSZ})$ is the most successful and widely used TBCs ceramic material, but it still has some problems. When serving at an environment higher than $1200{ }^{\circ} \mathrm{C}$ for a long time, $8 \mathrm{YSZ}$ will experience the phase transformation, sintering and corrosion aggravation, accompanied by degradation of thermal-physical and mechanical properties and reduction of strain tolerance, eventually leading to premature failure [6-8]. Therefore, it is urgent to develop new TBCs materials with excellent comprehensive thermodynamic properties in order to meet the development needs of the next generation aero-engine.

Among all the candidate TBCs materials, rare earth zirconates, especially $\mathrm{Sm}_{2} \mathrm{Zr}_{2} \mathrm{O}_{7}$ (SZO), have become one of the most potential candidate materials for the next generation of ultra-high temperature TBCs due to their high melting point, low thermal conductivity, good high-temperature phase stability and sintering resistance properties. Compared with 8YSZ $\left(2.2 \mathrm{~W} \cdot \mathrm{m}^{-1} \cdot \mathrm{K}^{-1}\right), \mathrm{Sm}_{2} \mathrm{Zr}_{2} \mathrm{O}_{7}$ ceramic has lower thermal conductivity $\left(1.6 \mathrm{~W} \cdot \mathrm{m}^{-1} \cdot \mathrm{K}^{-1}\right)$, and still maintains good high-temperature stability at $1900{ }^{\circ} \mathrm{C}[9,10]$. However, the thermal insulation of rare earth zirconates decreases by about $10 \%$ at above $800{ }^{\circ} \mathrm{C}$ due to the increased photon conduction. In order to improve the thermal insulation performance of rare earth zirconate, so it is 
necessary to increase the phonon scattering and weaken the role of photon conduction at high temperature, thus reducing the thermal conductivity. The effective methods to reduce the thermal conductivity mainly include the following: nanocrylation of materials, increasing defects (such as introducing substitution point defect, oxidation vacancy through ion doping, etc.), and the second phase doping with lower thermal conductivity [11]. Zhang et al. showed that the doping of $\mathrm{La}_{2} \mathrm{O}_{3}$, $\mathrm{Gd}_{2} \mathrm{O}_{3}$ and $\mathrm{Yb}_{2} \mathrm{O}_{3}$ could improve the thermophysical properties of $\mathrm{Sm}_{2} \mathrm{Zr}_{2} \mathrm{O}_{7}$ materials [12]. Compared with that of undoped $\mathrm{Sm}_{2} \mathrm{Zr}_{2} \mathrm{O}_{7}$, the thermal conductivity of $\left(\mathrm{Sm}_{0.75} \mathrm{La}_{0.25}\right)_{2} \mathrm{Zr}_{2} \mathrm{O}_{7}$ and $\left(\mathrm{Sm}_{0.5} \mathrm{La}_{0.5}\right)_{2} \mathrm{Zr}_{2} \mathrm{O}_{7}$ was obvious lower. In addition, the poor mechanical properties of $\mathrm{Sm}_{2} \mathrm{Zr}_{2} \mathrm{O}_{7}$ seriously affect the thermal cycle life of $\mathrm{Sm}_{2} \mathrm{Zr}_{2} \mathrm{O}_{7}$ coating, so it is urgent to improve its mechanical properties. Guo et al. reported that the fracture toughness of $\left(\mathrm{Sm}_{0.9} \mathrm{Sc}_{0.1}\right)_{2} \mathrm{Zr}_{2} \mathrm{O}_{7}$ synthesized by chemical co-precipitation was improved by nearly $50 \%$, compared with that of pure $\mathrm{Sm}_{2} \mathrm{Zr}_{2} \mathrm{O}_{7}$ [13]. Most of the reported literatures mainly focused on the influence of $\mathrm{La}, \mathrm{Gd}$, $\mathrm{Yb}, \mathrm{Sc}$ and other elements doping on the single aspect of thermophysical or mechanical properties of rare earth zirconate, however, there are few studies on the comprehensive properties such as thermophysical, mechanical and sintering resistance properties.

In this paper, a series of $\left(\mathrm{Sm}_{1-x l} \mathrm{Y}_{x 1}\right)_{2}\left(\mathrm{Zr}_{1-x 2} \mathrm{Y}_{x 2}\right)_{2} \mathrm{O}_{7-x 2}$ ceramics were prepared by high-temperature solid phase method. $\mathrm{Zr}^{4+}$ and $\mathrm{Sm}^{3+}$ ions in $\mathrm{Sm}_{2} \mathrm{Zr}_{2} \mathrm{O}_{7}$ crystal cells were replaced by $\mathrm{Y}^{3+}$ ions, respectively. The effects of $\mathrm{Y}^{3+}$ doping concentration and different substituent lattice positions on microstructure, phase composition, thermal conductivity, mechanical and high-temperature sintering resistance properties of modified $\mathrm{Sm}_{2} \mathrm{Zr}_{2} \mathrm{O}_{7}$ ceramics were investigated. The aim is to provide scientific support for the application of $\mathrm{A}_{2} \mathrm{~B}_{2} \mathrm{O}_{7}$ rare earth zirconates in engines.

\section{Experimental procedure}

\subsection{Specimen preparation}

$\mathrm{Sm}_{2} \mathrm{O}_{3}, \mathrm{ZrO}_{2}$ and $\mathrm{Y}_{2} \mathrm{O}_{3}$ (purity higher than 99.99\%) were used as raw materials to prepare $\mathrm{Sm}_{2} \mathrm{Zr}_{2} \mathrm{O}_{7}$ series ceramics with different lattice positions replaced by $\mathrm{Y}^{3+}$ ions through high-temperature solid phase sintering method. $\mathrm{Sm}_{2} \mathrm{O}_{3}, \mathrm{ZrO}_{2}$ and $\mathrm{Y}_{2} \mathrm{O}_{3}$ powders were sintered at 
$1000{ }^{\circ} \mathrm{C}$ for $4 \mathrm{~h}$ before weighing to remove water molecules and carbon oxides in the oxides. The above oxides were then weighed in a certain proportion, the anhydrous ethanol was used as the ball milling medium, and mechanical ball milling was carried out at the speed of 360r/min for $12 \mathrm{~h}$. Subsequently, the dried powder was pressed into the green ceramic body, and a series of $\left(\mathrm{Sm}_{1-x l} \mathrm{Y}_{x 1}\right)_{2}\left(\mathrm{Zr}_{1-x 2} \mathrm{Y}_{x 2}\right)_{2} \mathrm{O}_{7-x 2}$ ceramics were obtained after sintering at $1580{ }^{\circ} \mathrm{C}$ for $8 \mathrm{~h}$. The sintering behavior of $\left(\operatorname{Sm}_{1-x l} \mathrm{Y}_{x 1}\right)_{2}\left(\mathrm{Zr}_{1-x 2} \mathrm{Y}_{x 2}\right)_{2} \mathrm{O}_{7-x 2}$ ceramics was studied by testing the grain size, distribution and phase structure of the samples sintered at $1400{ }^{\circ} \mathrm{C}$ for different times.

\subsection{Microstructure and performances characterization}

The surface microstructure of the samples was characterized by scanning electron microscope (SEM, Phenom XL, Netherlands) with energy disperse spectroscopy (EDS). Rigaku Ultima IV X-ray diffractometer (XRD) was used to analyze the phase composition of the sample. The scanning angle is $10^{\circ} \sim 90^{\circ}$, and the range of $28^{\circ} \sim 31^{\circ}$ is slowly scanned to calculate the lattice constant of the sample. According to the different characteristics of Raman spectroscopy sensitivity to pyrochlore structure and fluorite structure, the phase composition of the samples was further determined by a laser confocal Raman spectrometer (Renishaw inVia Raman Microscope, UK) with the $532 \mathrm{~nm}$ Raman Laser wavelength. The ultrasonic pulse generator receiver (Olympus 5058 PR, USA) is used to measure the longitudinal sound velocity $\left(v_{1}\right)$ and transverse sound velocity $\left(v_{\mathrm{s}}\right)$ of the samples, and then the average sound velocity $v$ is obtained through the $E q$. (1). Meanwhile, the elastic modulus $\left(\mathrm{E}_{\Phi}\right)$ of the samples can be calculated from the acoustic velocities by Eq. (2). The elastic modulus $\left(\mathrm{E}_{\Phi}\right)$ is extrapolated to the elastic modulus $\left(\mathrm{E}_{0}\right)$ with full density by the following Eq. (3) because of the influence of micropores on the elastic modulus [14].

$$
\begin{gathered}
v=3^{\frac{1}{3}} \cdot\left(\frac{1}{v_{1}^{3}}+\frac{2}{v_{s}^{3}}\right)^{\frac{-1}{3}} \\
E(\Phi)=\rho v_{s}^{2} \frac{3 v_{1}^{2}-4 v_{s}^{2}}{v_{1}^{2}-v_{s}^{2}} \\
E_{0}=\frac{E_{\Phi}}{\left(1-\Phi^{2 / 3}\right)^{1.21}}
\end{gathered}
$$


The Vickers hardness and fracture toughness of the sample were measured by the indentation method. After polishing the sample surface, ten indentations on each sample surface were prepared with a Vickers hardness tester (MH-5LD China, load $1000 \mathrm{gf}$, holding time $20 \mathrm{~s}$ ) to take the average value to avoid accidental errors. The size of the indentations and cracks were tested with a scanning electron microscope $(\mathrm{SEM})$, and then Vickers hardness $(H \mathrm{v})$ and fracture toughness $\left(K_{\mathrm{IC}}\right)$ were calculated following the Eq. (4) and Eq. (5) [15].

$$
\begin{gathered}
H v=0.464 \frac{P}{a^{2}} \\
K_{I C}=0.018 \cdot\left(\frac{E}{H v}\right)^{\frac{1}{2}}\left(\frac{P}{c^{\frac{3}{2}}}\right)
\end{gathered}
$$

In the above formulas, $P$ - load pressure $(\mathrm{N})$; E - Young's modulus value (GPa). Where $a$ is the half length of the indentation diagonal, and $c$ is the distance from the center of the indentation to the crack tip. The thermal diffusivity $(\alpha)$ was measured by a laser flash apparatus (Netzsch LFA427 HT HyperFlash, German) in an argon atmosphere from room temperature to $1200{ }^{\circ} \mathrm{C}$. The specific heat capacity $(\mathrm{C} p)$ is calculated by the Neumann-Kopp rule. The density $(\rho)$ of the sample was measured by Archimedes method in distilled water. The thermal conductivity $(\lambda)$ of sample was obtained through the Eq. (6). Because it is difficult to prepare a completely dense sample, the actual thermal conductivity $(\lambda)$ is corrected to $\left(\lambda_{0}\right)$ as shown in $E q .(7)$, where $\Phi$ is the porosity [16, 17$]$.

$$
\begin{aligned}
& \lambda=\rho \cdot \alpha \cdot C_{P} \\
& \frac{\lambda}{\lambda_{0}}=1-\frac{4 \Phi}{3}
\end{aligned}
$$

\section{Result and Discussion}

\subsection{Phase composition and Microstructure}

Fig. 1 showed the XRD patterns of $\left(\mathrm{Sm}_{1-x l} \mathrm{Y}_{x 1}\right)_{2}\left(\mathrm{Zr}_{1-x 2} \mathrm{Y}_{x 2}\right)_{2} \mathrm{O}_{7-x 2}$ ceramics with different lattice positions replaced by $\mathrm{Y}^{3+}$ ions. It could be found that the substitution of $\mathrm{Y}^{3+}$ ions in different positions had almost no effect on the diffraction peaks of $\mathrm{Sm}_{2} \mathrm{Zr}_{2} \mathrm{O}_{7}$, meanwhile no new phases were formed. According to the reported literature [18], there were some characteristic peaks for $\mathrm{A}_{2} \mathrm{~B}_{2} \mathrm{O}_{7}$ type 
compounds at $14^{\circ}(111), 27^{\circ}(311), 37^{\circ}(331), 45^{\circ}$ (511), suggesting that the $\mathrm{A}_{2} \mathrm{~B}_{2} \mathrm{O}_{7}$ compound belonged to the pyrochlore crystal lattice. The characteristic peaks for $\mathrm{A}_{2} \mathrm{~B}_{2} \mathrm{O}_{7}$ type compounds also appeared in the XRD diffraction peaks of $\left(\mathrm{Sm}_{1-x l} \mathrm{Y}_{x 1}\right)_{2}\left(\mathrm{Zr}_{1-x 2} \mathrm{Y}_{x 2}\right)_{2} \mathrm{O}_{7-x 2}$ ceramics. The characteristic peaks of the crystal plane and these characteristic peaks correspond to the ordered pyrochlore phase structure, indicating that the substitution of $\mathrm{Y}^{3+}$ ions in different positions did not change the pyrochlore structure of $\mathrm{Sm}_{2} \mathrm{Zr}_{2} \mathrm{O}_{7}$. In other words, the crystal cells of $\left(\mathrm{Sm}_{1-x 1} \mathrm{Y}_{x 1}\right)_{2}\left(\mathrm{Zr}_{1-x 2} \mathrm{Y}_{x 2}\right)_{2} \mathrm{O}_{7-x 2}$ were still pyrochlore structure.

Comparing the diffraction peaks of $\left(\mathrm{Sm}_{1-x l} \mathrm{Y}_{x 1}\right)_{2}\left(\mathrm{Zr}_{1-x 2} \mathrm{Y}_{x 2}\right)_{2} \mathrm{O}_{7-x 2}$ ceramics with the standard PDF card of $\mathrm{Sm}_{2} \mathrm{Zr}_{2} \mathrm{O}_{7}$, the diffraction peak tended to shift to a small Angle when the $\mathrm{Zr}^{4+}$ ions in the B lattice position of $\mathrm{A}_{2} \mathrm{~B}_{2} \mathrm{O}_{7}$ was partially replaced by $\mathrm{Y}^{3+}$ ions, as shown in Fig. 2(A). This is because the ionic radius of $\mathrm{Y}^{3+}(0.9 \AA)$ is larger than that of $\mathrm{Zr}^{4+}(0.72 \AA)$. When $\mathrm{Y}^{3+}$ ions partially occupied the $\mathrm{Zr}^{4+}$ lattices, the lattice constant increased, which was consistent with the Bragg diffraction formula, namely, the diffraction Angle decreased with the increase of crystal plane spacing. The crystal cell parameters of $\left(\mathrm{Sm}_{1-x l} \mathrm{Y}_{x 1}\right)_{2}\left(\mathrm{Zr}_{1-x 2} \mathrm{Y}_{x 2}\right)_{2} \mathrm{O}_{7-x 2}$ ceramics were shown in Fig. 2(B). Theoretically, when $\mathrm{Sm}^{3+}$ ions in A-lattice is substituted by $\mathrm{Y}^{3+}$ ions with small radius, the lattice constant should decrease and the diffraction Angle should shift to a large Angle. However, its lattice constant abnormally increased when $\mathrm{Y}^{3+}$ ion replaced $\mathrm{Sm}^{3+}$ ion in $\mathrm{Sm}_{2} \mathrm{Zr}_{2} \mathrm{O}_{7}$. Wang et al. [11] showed that $\mathrm{Y}^{3+}$ could replace both $\mathrm{La}^{3+}$ and $\mathrm{Zr}^{4+}$ ion lattice positions with the doping of $\mathrm{Y}^{3+}$ ions in $\mathrm{La}_{2} \mathrm{Zr}_{2} \mathrm{O}_{7}\left[\left(\mathrm{La}_{1-x 1} \mathrm{Y}_{x 1}\right)_{2}\left(\mathrm{Zr}_{1-x 2} \mathrm{Y}_{x 2}\right)_{2} \mathrm{O}_{7-x 2}\right]$, resulting in a larger lattice constant. The increase of lattice constant caused by $\mathrm{Zr}^{4+}$ substitution offset or even exceeded the decrease of lattice constant caused by $\mathrm{Sm}^{3+}$ substitution, so the diffraction Angle of $\left(\mathrm{Sm}_{0.9} \mathrm{Y}_{0.1}\right)_{2} \mathrm{Zr}_{2} \mathrm{O}_{7},\left(\mathrm{Sm}_{0.8} \mathrm{Y}_{0.2}\right)_{2} \mathrm{Zr}_{2} \mathrm{O}_{7}$ ceramics were slightly shifted to a small Angle, and the deviation Angle increased with the increase of the proportion of $\mathrm{Y}^{3+}$ ions.

In order to further determine the phase structure of $\left(\mathrm{Sm}_{1-x 1} \mathrm{Y}_{x 1}\right)_{2}\left(\mathrm{Zr}_{1-x 2} \mathrm{Y}_{x 2}\right)_{2} \mathrm{O}_{7-x 2}$ ceramics, the samples were analyzed by Raman spectroscopy. Fig. 3 showed the Raman spectrum of $\left(\mathrm{Sm}_{1-x 1} \mathrm{Y}_{x 1}\right)_{2}\left(\mathrm{Zr}_{1-x 2} \mathrm{Y}_{x 2}\right)_{2} \mathrm{O}_{7-x 2}$ ceramics. Based on the symmetry of the point group of the unit cell structure, it can be seen that the rare earth zirconates with a pyrochlore structure has six Raman vibration modes, as shown in Eq. (8):

$$
\Gamma(R)=A_{1 g}+E_{g}+4 T_{2 g}
$$


$\left(\mathrm{Sm}_{1-x I} \mathrm{Y}_{x I}\right)_{2}\left(\mathrm{Zr}_{1-x 2} \mathrm{Y}_{x 2}\right)_{2} \mathrm{O}_{7-x 2}$ ceramics had four characteristic peaks at around $305 \mathrm{~cm}^{-1}, 395 \mathrm{~cm}^{-1}, 530$ $\mathrm{cm}^{-1}$ and $595 \mathrm{~cm}^{-1}$, which were Raman spectrum vibration peaks of typical pyrochlore structure compounds. The $\mathrm{A}_{1 \mathrm{~g}}$ mode at around $530 \mathrm{~cm}^{-1}$ corresponds to the characteristic band of $\mathrm{Sm}(\mathrm{Y})-\mathrm{O}$ stretching vibration in the pyrochlore structure. The $\mathrm{T}_{2 \mathrm{~g}}$ mode around $395 \mathrm{~cm}^{-1}$ is the $\mathrm{Zr}(\mathrm{Y})-\mathrm{O}$ stretching peak. The $\mathrm{E}_{\mathrm{g}}$ mode at $305 \mathrm{~cm}^{-1}$ is $\mathrm{O}-\mathrm{Sm}(\mathrm{Y})-\mathrm{O}$ bending vibration and the $\mathrm{T}_{2 \mathrm{~g}}$ mode is $\mathrm{Sm}(\mathrm{Y})-\mathrm{O}$ stretching vibration at about $595 \mathrm{~cm}^{-1}$. Compared with the $\mathrm{Sm}_{2} \mathrm{Zr}_{2} \mathrm{O}_{7}$ ceramic, no matter whether $\mathrm{Y}^{3+}$ ions replaced the A or B lattice in $\mathrm{Sm}_{2} \mathrm{Zr}_{2} \mathrm{O}_{7}$, the vibration intensity of the Raman characteristic peaks at around $305 \mathrm{~cm}^{-1}, 395 \mathrm{~cm}^{-1}, 530 \mathrm{~cm}^{-1}$ and $595 \mathrm{~cm}^{-1}$ always decreased with the increase of the doping amount of $\mathrm{Y}^{3+}$ ions and the spectral band became wider. It was considered to be caused by the decrease in the order of $\left(\mathrm{Sm}_{1-x l} \mathrm{Y}_{x 1}\right)_{2}\left(\mathrm{Zr}_{1-x 2} \mathrm{Y}_{x 2}\right)_{2} \mathrm{O}_{7-x 2}$ crystal structure. The above results were basically the same as the reported literature [19].

Fig. 4 presented the surface SEM images of $\left(\operatorname{Sm}_{1-x I} \mathrm{Y}_{x 1}\right)_{2}\left(\mathrm{Zr}_{1-x 2} \mathrm{Y}_{x 2}\right)_{2} \mathrm{O}_{7-x 2}$ ceramics with different lattice positions replaced by $\mathrm{Y}^{3+}$ ions. As could be seen from the Fig. 4 that grain boundaries between grains of sintered $\left(\mathrm{Sm}_{1-x l} \mathrm{Y}_{x 1}\right)_{2}\left(\mathrm{Zr}_{1-x 2} \mathrm{Y}_{x 2}\right)_{2} \mathrm{O}_{7-x 2}$ ceramics were clear. The grain shapes were regular and polygonal, and there were some micropores among the grains. In addition, with the increase of the $\mathrm{Y}^{3+}$ ions substitution concentration, the number of pores gradually decreased and tended to compact. The calculated porosity of $\left(\mathrm{Sm}_{1-x l} \mathrm{Y}_{x 1}\right)_{2}\left(\mathrm{Zr}_{1-x 2} \mathrm{Y}_{x 2}\right)_{2} \mathrm{O}_{7-x 2}$ ceramics was $17 \%, 18 \%, 13 \%, 8 \%$ and $2 \%$, respectively. Therefore, the porosity of $\mathrm{Sm}_{2} \mathrm{Zr}_{2} \mathrm{O}_{7}$ ceramics could be significantly reduced by $\mathrm{Y}^{3+}$ ions replacing $\mathrm{Sm}^{3+}$ ions or $\mathrm{Zr}^{4+}$ ions lattices in $\mathrm{Sm}_{2} \mathrm{Zr}_{2} \mathrm{O}_{7}$ ceramic. On the one hand, when $\mathrm{Y}^{3+}$ ions replaced the $\mathrm{Sm}^{3+}$ ions lattices in $\mathrm{Sm}_{2} \mathrm{Zr}_{2} \mathrm{O}_{7}$ (as shown in Fig. $4 \mathrm{~b}$ and Fig. 4c), the crystal grains slightly grew with the increase of $\mathrm{Y}^{3+}$ ions doping concentration. When $\mathrm{Y}^{3+}$ ions replaced the $\mathrm{Zr}^{4+}$ ions lattices in $\mathrm{Sm}_{2} \mathrm{Zr}_{2} \mathrm{O}_{7}$ (as shown in Fig. 4 d and Fig. 4e), the material density had significantly increased, but the grain growth trend became more significant with the increase of $\mathrm{Y}^{3+}$ ions doping concentration.

\subsection{Thermal conductivity}

According to Neumann-Kopp rule, the specific heat capacities of $\left(\operatorname{Sm}_{1-x x} \mathrm{Y}_{x 1}\right)_{2}\left(\mathrm{Zr}_{1-x 2} \mathrm{Y}_{x 2}\right)_{2} \mathrm{O}_{7-x 2}$ compounds are equal to the weighted sum of the specific heat capacity of $\mathrm{Sm}_{2} \mathrm{O}_{3}, \mathrm{ZrO}_{2}$ and $\mathrm{Y}_{2} \mathrm{O}_{3}$. The specific heat capacities of $\left(\operatorname{Sm}_{1-x l} \mathrm{Y}_{x 1}\right)_{2}\left(\mathrm{Zr}_{1-x 2} \mathrm{Y}_{x 2}\right)_{2} \mathrm{O}_{7-x 2}$ ceramics were calculated from room temperature to $1200{ }^{\circ} \mathrm{C}$ through the Neumann-Kopp rule, as seen in Fig. 5. The specific heat capacities 
of $\left(\mathrm{Sm}_{1-x l} \mathrm{Y}_{x l}\right)_{2}\left(\mathrm{Zr}_{1-x 2} \mathrm{Y}_{x 2}\right)_{2} \mathrm{O}_{7-x 2}$ ceramics ranged from $0.38 \mathrm{~J} \cdot \mathrm{g}^{-1} \cdot \mathrm{K}^{-1}$ to $0.54 \mathrm{~J} \cdot \mathrm{g}^{-1} \cdot \mathrm{K}^{-1}$. The specific heat capacity of each $\left(\mathrm{Sm}_{1-x l} \mathrm{Y}_{x 1}\right)_{2}\left(\mathrm{Zr}_{1-x 2} \mathrm{Y}_{x 2}\right)_{2} \mathrm{O}_{7-x 2}$ ceramic increased with the increase of temperature. When $\mathrm{Y}^{3+}$ ions were substituted for $\mathrm{Sm}^{3+}$ ions in $\mathrm{Sm}_{2} \mathrm{Zr}_{2} \mathrm{O}_{7}$, the specific heat capacity slightly increased with the rise of the $\mathrm{Y}^{3+}$ concentration. On the contrary, when the $\mathrm{Zr}^{4+}$ ions were replaced, the specific heat capacity would decrease with the rise of $\mathrm{Y}^{3+}$ concentration.

Fig. 6 showed the thermal diffusivity-temperature curves of $\left(\operatorname{Sm}_{1-x l} Y_{x 1}\right)_{2}\left(\operatorname{Zr}_{1-x 2} Y_{x 2}\right)_{2} \mathrm{O}_{7-x 2}$ ceramics. Thermal diffusivities of $\left(\operatorname{Sm}_{1-x I} \mathrm{Y}_{x I}\right)_{2}\left(\mathrm{Zr}_{1-x 2} \mathrm{Y}_{x 2}\right)_{2} \mathrm{O}_{7-x 2}$ ceramics decreased with the temperature rising. This trend could be divided into three stages: First, the thermal diffusivities of $\left(\mathrm{Sm}_{1-x I} \mathrm{Y}_{x 1}\right)_{2}\left(\mathrm{Zr}_{1-x 2} \mathrm{Y}_{x 2}\right)_{2} \mathrm{O}_{7-x 2}$ ceramics decreased with the temperature rising below $800{ }^{\circ} \mathrm{C}$. The phonon conduction plays a vital role in heat conduction at lower temperatures $\left(\leq 800{ }^{\circ} \mathrm{C}\right)$ for most inorganic non-metallic materials, and phonon scattering gradually enhanced with the increase of temperature [20]. Second, the thermal diffusivities did not significantly change in the range of $800 \sim 1000{ }^{\circ} \mathrm{C}$. This phenomenon was due to the increasing proportion of photon conduction (thermal radiation) in the heat conduction of materials at above $800{ }^{\circ} \mathrm{C}$. Thirdly, the thermal diffusivities slowly decreased with the increase of temperature. This result was basically consistent with the variation trend of thermal diffusivities of $\mathrm{Yb}^{3+}$ doped $\mathrm{Gd}_{2} \mathrm{Zr}_{2} \mathrm{O}_{7}$ ceramics in the range of $1000 \sim 1200{ }^{\circ} \mathrm{C}$ reported in literature [16]. In addition, $\mathrm{Sm}_{2}\left(\mathrm{Zr}_{0.9} \mathrm{Y}_{0.1}\right)_{2} \mathrm{O}_{6.9}$ had the lowest thermal diffusivity in the studied $\left(\mathrm{Sm}_{1-x l} \mathrm{Y}_{x I}\right)_{2}\left(\mathrm{Zr}_{1-x 2} \mathrm{Y}_{x 2}\right)_{2} \mathrm{O}_{7-x 2}$ ceramics between room temperature and $1200{ }^{\circ} \mathrm{C}$.

According to the measured thermal diffusivity $(\alpha)$, heat capacity value $\left(C_{\mathrm{p}}\right)$ and density $(\rho)$, thermal conductivity of the fully dense $\left(\operatorname{Sm}_{1-x l} \mathrm{Y}_{x 1}\right)_{2}\left(\mathrm{Zr}_{1-x 2} \mathrm{Y}_{x 2}\right)_{2} \mathrm{O}_{7-x 2}$ series ceramics were calculated and the effect of porosity was eliminated through Eqs. (6) and (7). Thermal conductivity of $\left(\mathrm{Sm}_{1-x I} \mathrm{Y}_{x 1}\right)_{2}\left(\mathrm{Zr}_{1-x 2} \mathrm{Y}_{x 2}\right)_{2} \mathrm{O}_{7-x 2}$ versus temperatures were shown in Fig. 7. Thermal conductivity significantly decreased with the increase of temperature at below $800{ }^{\circ} \mathrm{C}$ due to the effect of the phonon scattering mechanism. Thermal conductivity had a slight increase in the range $800{ }^{\circ} \mathrm{C}$ to $1000{ }^{\circ} \mathrm{C}$, which was due to the gradual enhancement of photon conduction at high temperatures [21-23]. 
In addition, thermal conductivity $(\boldsymbol{\kappa})$ of the material is inversely proportional to the phonon scattering rate $(\Gamma)$, as shown in $E q$. (8). The phonon scattering rate $(\Gamma)$ of the pyrochlore-type $\mathrm{A}_{2} \mathrm{~B}_{2} \mathrm{O}_{7}$ material is the integral of the lattice scattering coefficients of the three elements A, B, and O, as shown in Eq. (9).

$$
\begin{aligned}
& \kappa \propto \frac{1}{\Gamma} \\
& \Gamma=\frac{1}{6}\left(\frac{M_{A}}{\bar{M}}\right)^{2} \Gamma_{A}+\frac{1}{6}\left(\frac{M_{B}}{\bar{M}}\right)^{2} \Gamma_{B}+\frac{2}{3}\left(\frac{M_{O}}{\bar{M}}\right)^{2} \Gamma_{O}
\end{aligned}
$$

Thermal conductivity of $\left(\mathrm{Sm}_{0.9} \mathrm{Y}_{0.1}\right)_{2} \mathrm{Zr}_{2} \mathrm{O}_{7}$ was similar to that of $\left(\mathrm{Sm}_{0.8} \mathrm{Y}_{0.2}\right)_{2} \mathrm{Zr}_{2} \mathrm{O}_{7}$, as seen in Fig. 7. On the one hand, this was due to the lattice distortion produced by the substitution of $\mathrm{Y}^{3+}$ ions for $\mathrm{Sm}^{3+}$ ions. As a defect, lattice distortion can directly enhance phonon scattering and reduce the mean free path of phonons, thus reducing the thermal conductivity. On the other hand, according to the thermal conductivity calculation Eq. (10) proposed by Clarke, thermal conductivity of the material is inversely proportional to the relative molecular weight of the compound. Although the lattice distortion was generated by the substitution of $\mathrm{Y}^{3+}$ ions with $\mathrm{Sm}^{3+}$ ions, it also led to the reduction of the relative molecular weight. The interaction of the two above factors brought about the close thermal conductivity of $\left(\mathrm{Sm}_{0.9} \mathrm{Y}_{0.1}\right)_{2} \mathrm{Zr}_{2} \mathrm{O}_{7}$ and $\left(\mathrm{Sm}_{0.8} \mathrm{Y}_{0.2}\right)_{2} \mathrm{Zr}_{2} \mathrm{O}_{7}$.

$$
k_{\min }=0.87 k_{\mathrm{B}} N_{\mathrm{A}}^{2 / 3} \frac{m^{2 / 3} \rho^{1 / 6} E^{1 / 2}}{M^{2 / 3}}
$$

$k_{\min }$ is the theoretical minimum thermal conductivity of the material (the mean free path of phonons at this time is equal to the average distance between atoms); $m$ is the number of atoms in the molecule; $E$ is the Young's modulus; $M$ is the relative molecular mass. In addition, thermal conductivity of $\mathrm{Sm}_{2}\left(\mathrm{Zr}_{0.9} \mathrm{Y}_{0.1}\right)_{2} \mathrm{O}_{6.9}$ was significantly lower than that of $\mathrm{Sm}_{2}\left(\mathrm{Zr}_{0.8} \mathrm{Y}_{0.2}\right)_{2} \mathrm{O}_{6.8}$. It was the result of synergistic action of lattice defects, oxygen vacancy and relative mass reduction caused by the substitution of $\mathrm{Y}^{3+}$ ions for the $\mathrm{Zr}^{4+}$ ions. For $\mathrm{Sm}_{2} \mathrm{Zr}_{2} \mathrm{O}_{7}$, thermal conductivity of $\mathrm{Zr}^{4+}$ lattice replacement was obviously lower than that of $\mathrm{Sm}^{3+}$ lattice replacement. Whether $\mathrm{Y}^{3+}$ ions was substituted for $\mathrm{Sm}^{3+}$ ions or $\mathrm{Zr}^{4+}$ ions in $\mathrm{Sm}_{2} \mathrm{Zr}_{2} \mathrm{O}_{7}$, the decrease of thermal conductivity would be caused. Thermal conductivity of the corresponding $\left(\mathrm{Sm}_{1-x l} \mathrm{Y}_{x 1}\right)_{2}\left(\mathrm{Zr}_{1-x 2} \mathrm{Y}_{x 2}\right)_{2} \mathrm{O}_{7-x 2}$ ceramics was significantly lower than that of the traditional $8 \mathrm{YSZ}$ ceramic $\left(2.2 \mathrm{~W} \cdot \mathrm{m}^{-1} \cdot \mathrm{k}^{-1}, 1000^{\circ} \mathrm{C}\right)$. $\mathrm{Sm}_{2}\left(\mathrm{Zr}_{0.9} \mathrm{Y}_{0.1}\right)_{2} \mathrm{O}_{6.9}$ had the lowest thermal conductivity among the studied ceramics, and thermal conductivity at $1200{ }^{\circ} \mathrm{C}$ was $1.315 \mathrm{~W} \cdot \mathrm{m}^{-1} \cdot \mathrm{K}^{-1}$. Therefore, $\left(\mathrm{Sm}_{1-x I} \mathrm{Y}_{x 1}\right)_{2}\left(\mathrm{Zr}_{1-x 2} \mathrm{Y}_{x 2}\right)_{2} \mathrm{O}_{7-x 2}$ ceramics with pyrochlore structure were still a kind of potential TBCs material with low thermal conductivity. 


\subsection{Mechanical properties}

Fracture toughness is a measure of a material's ability to prevent macroscopic crack propagation and also a toughness parameter of the material's resistance to brittle failure. Additionally, the lower Young's modulus helps to relieve the thermal stress of the coating during high-temperature service, which can further extend the service life of the coating. Table 1 showed the mechanical properties of $\left(\mathrm{Sm}_{1-x l} \mathrm{Y}_{x 1}\right)_{2}\left(\mathrm{Zr}_{1-x 2} \mathrm{Y}_{x 2}\right)_{2} \mathrm{O}_{7-x 2}$ ceramics. The hardness of $\left(\mathrm{Sm}_{0.9} \mathrm{Y}_{0.1}\right)_{2} \mathrm{Zr}_{2} \mathrm{O}_{7}$ ceramic was smaller than that of $\left(\mathrm{Sm}_{0.8} \mathrm{Y}_{0.2}\right)_{2} \mathrm{Zr}_{2} \mathrm{O}_{7}$ ceramic. When $\mathrm{Y}^{3+}$ ions were substituted for the $\mathrm{Zr}^{4+}$ ions lattice in $\mathrm{Sm}_{2} \mathrm{Zr}_{2} \mathrm{O}_{7}$, the hardness of $\mathrm{Sm}_{2}\left(\mathrm{Zr}_{1-x 2} \mathrm{Y}_{x 2}\right)_{2} \mathrm{O}_{7-x 2}$ was significantly improved, compared with that of pure $\mathrm{Sm}_{2} \mathrm{Zr}_{2} \mathrm{O}_{7}$, but the hardness of $\mathrm{Sm}_{2}\left(\mathrm{Zr}_{0.9} \mathrm{Y}_{0.1}\right)_{2} \mathrm{O}_{6.9}$ was close to that of $\mathrm{Sm}_{2}\left(\mathrm{Zr}_{0.8} \mathrm{Y}_{0.2}\right)_{2} \mathrm{O}_{6.8}$. $\mathrm{Sm}_{2}\left(\mathrm{Zr}_{0.9} \mathrm{Y}_{0.1}\right)_{2} \mathrm{O}_{6.9}$ has the highest hardness among the studied ceramic materials.

When the $\mathrm{Zr}^{4+}$ ion lattice in $\mathrm{Sm}_{2} \mathrm{Zr}_{2} \mathrm{O}_{7}$ was replaced by $\mathrm{Y}^{3+}$ ion, the elastic modulus of $\mathrm{Sm}_{2}\left(\mathrm{Zr}_{1-x 2} \mathrm{Y}_{x 2}\right)_{2} \mathrm{O}_{7-x 2}$ significantly increased, which was consistent with the changing trend of hardness. When the $\mathrm{Zr}^{4+}$ ion lattice of $\mathrm{Sm}_{2} \mathrm{Zr}_{2} \mathrm{O}_{7}$ was replaced by $\mathrm{Y}^{3+}$ ion, the elastic modulus of the obtained ceramic was obviously higher than that of $\mathrm{Sm}^{3+}$ ion lattice replaced. This was closely related to the microstructure of $\mathrm{Y}$ modified $\mathrm{Sm}_{2} \mathrm{Zr}_{2} \mathrm{O}_{7}$ ceramics. Compared with the $\left(\mathrm{Sm}_{1-x 1} \mathrm{Y}_{x 1}\right)_{2} \mathrm{Zr}_{2} \mathrm{O}_{7}$ ceramics with $\mathrm{Sm}^{3+}$ ion lattice replaced by $\mathrm{Y}^{3+}$ ion, $\operatorname{Sm}_{2}\left(\mathrm{Zr}_{1-x 2} \mathrm{Y}_{x 2}\right)_{2} \mathrm{O}_{7-x 2}$ ceramics had larger grains and denser microstructures (as shown in Fig. 4). ( $\left.\mathrm{Sm}_{0.9} \mathrm{Y}_{0.1}\right)_{2} \mathrm{Zr}_{2} \mathrm{O}_{7}$ exhibited the smallest elastic modulus, but the change rule of fracture toughness was slightly different. Whether $\mathrm{Sm}^{3+}$ or $\mathrm{Zr}^{4+}$ was replaced, the fracture toughness of ceramics was significantly reduced. Especially, the fracture toughness of $\left(\mathrm{Sm}_{0.8} \mathrm{Y}_{0.2}\right)_{2} \mathrm{Zr}_{2} \mathrm{O}_{7}$ was the lowest. The fracture toughness of $\mathrm{Sm}_{2}\left(\mathrm{Zr}_{0.9} \mathrm{Y}_{0.1}\right)_{2} \mathrm{O}_{6.9}$ ceramic was better than that of $\mathrm{Sm}_{2}\left(\mathrm{Zr}_{0.9} \mathrm{Y}_{0.2}\right)_{2} \mathrm{O}_{6.8}$.

Table 1 Mechanical properties of $\left(\mathrm{Sm}_{1-x l} \mathrm{Y}_{x 1}\right)_{2}\left(\mathrm{Zr}_{1-x 2} \mathrm{Y}_{x 2}\right)_{2} \mathrm{O}_{7-x 2}$ ceramics

\begin{tabular}{cccccc}
\hline & $\mathrm{a}$ & $\mathrm{b}$ & $\mathrm{c}$ & $\mathrm{d}$ & $\mathrm{e}$ \\
\hline $\mathrm{Hv} / \mathrm{GPa}$ & 6.50 & 5.35 & 7.98 & 10.30 & 10.10 \\
\hline $\mathrm{E} / \mathrm{GPa}$ & 166.6 & 154.0 & 174.5 & 194.8 & 195.7 \\
\hline $\begin{array}{c}\mathrm{K} \mathrm{IC} \\
/ \mathrm{MPa} \cdot \mathrm{m}^{1 / 2}\end{array}$ & 1.70 & 1.60 & 0.62 & 1.33 & 1.18 \\
\hline
\end{tabular}




\subsection{High-temperature sintering behavior}

$\mathrm{Sm}_{2}\left(\mathrm{Zr}_{0.9} \mathrm{Y}_{0.1}\right)_{2} \mathrm{O}_{6.9}$ ceramic with better comprehensive properties were sintered at $1400{ }^{\circ} \mathrm{C}$ for different times, and then the microstructure and phase composition were characterized so as to further explore its sintering behavior. Fig. 8 showed the microstructure of $\mathrm{Sm}_{2}\left(\mathrm{Zr}_{0.9} \mathrm{Y}_{0.1}\right)_{2} \mathrm{O}_{6.9}$ ceramic sintered at $1400{ }^{\circ} \mathrm{C}$ for different times. With the increase of sintering time, the density of the ceramics increased, the number of surface pores gradually decreased, and the grain size increased. The grain size was concentrated in the range of (1-2) $\mu \mathrm{m}$, but the grain growth trend was slow. In addition, no new phase was found in the $\mathrm{Sm}_{2}\left(\mathrm{Zr}_{0.9} \mathrm{Y}_{0.1}\right)_{2} \mathrm{O}_{6.9}$ ceramics after high-temperature sintering for a long time, showing excellent high-temperature stability.

It could be seen from Fig. 9 that the grain growth rate of $\mathrm{Sm}_{2} \mathrm{Zr}_{2} \mathrm{O}_{7}$ ceramic was faster before $25 \mathrm{~h}$ at $1400{ }^{\circ} \mathrm{C}$, and then the grain growth rate became slower with the further increase of sintering time, indicating that the grain growth of $\mathrm{Sm}_{2} \mathrm{Zr}_{2} \mathrm{O}_{7}$ was more obvious in unit time and the ability to resist sintering was weaker. Compared with pure $\mathrm{Sm}_{2} \mathrm{Zr}_{2} \mathrm{O}_{7}$ ceramic, the sintering rate of $\mathrm{Y}^{3+}$ doped $\mathrm{Sm}_{2} \mathrm{Zr}_{2} \mathrm{O}_{7}$ was obviously lower. The grain growth rates of $\left(\mathrm{Sm}_{0.9} \mathrm{Y}_{0.1}\right)_{2} \mathrm{Zr}_{2} \mathrm{O}_{7}$ and $\left(\mathrm{Sm}_{2}\left(\mathrm{Zr}_{0.9} \mathrm{Y}_{0.1}\right)_{2} \mathrm{O}_{6.9}\right.$ ceramics were basically the same before sintering $80 \mathrm{~h}$, and the grain size of both samples increased with the sintering time rising. As the sintering time continued to increase up to $100 \mathrm{~h}$, it was found that the grain growth rate of $\mathrm{Sm}_{2}\left(\mathrm{Zr}_{0.9} \mathrm{Y}_{0.1}\right)_{2} \mathrm{O}_{6.9}$ ceramic after the substitution of $\mathrm{Y}^{3+}$ ions for $\mathrm{Zr}^{4+}$ ion lattice was significantly lower than that of $\left(\mathrm{Sm}_{0.9} \mathrm{Y}_{0.1}\right)_{2} \mathrm{Zr}_{2} \mathrm{O}_{7}$. The sintering kinetics curves and microstructure of $\mathrm{Sm}_{2}\left(\mathrm{Zr}_{0.9} \mathrm{Y}_{0.1}\right)_{2} \mathrm{O}_{6.9}$ ceramic at $1400{ }^{\circ} \mathrm{C}$ indicated that $\mathrm{Sm}_{2}\left(\mathrm{Zr}_{0.9} \mathrm{Y}_{0.1}\right)_{2} \mathrm{O}_{6.9}$ had relatively good sintering resistance performance at $1400^{\circ} \mathrm{C}$. In order to further verify the high-temperature phase stability of $\mathrm{Sm}_{2}\left(\mathrm{Zr}_{0.9} \mathrm{Y}_{0.1}\right)_{2} \mathrm{O}_{6.9}$ ceramic, $\mathrm{XRD}$ analysis at different sintering times was carried out, as shown in Fig. 10. With the increase of sintering time, the phase composition of $\operatorname{Sm}_{2}\left(\mathrm{Zr}_{0.9} \mathrm{Y}_{0.1}\right)_{2} \mathrm{O}_{6.9}$ ceramic did not change, indicating that the sintering time had no obvious effect on the phase composition of $\mathrm{Sm}_{2}\left(\mathrm{Zr}_{0.9} \mathrm{Y}_{0.1}\right)_{2} \mathrm{O}_{6.9}$ ceramic, showing excellent high-temperature phase stability.

\section{Conclusion}

(1) $\left(\mathrm{Sm}_{1-x l} \mathrm{Y}_{x 1}\right)_{2}\left(\mathrm{Zr}_{1-x 2} \mathrm{Y}_{x 2}\right)_{2} \mathrm{O}_{7-x 2}$ were composed of a single pyrochlore crystal phase within $20 \% \mathrm{Y}^{3+}$ ions doping concentration, the XRD diffraction peaks were all offset to the small Angle direction, 
and $\mathrm{Sm}_{2}\left(\mathrm{Zr}_{1-x 2} \mathrm{Y}_{x 2}\right)_{2} \mathrm{O}_{7-x 2}$ had larger crystal grains and higher density.

(2) The Vickers hardness of $\operatorname{Sm}_{2}\left(\mathrm{Zr}_{1-x 2} \mathrm{Y}_{x 2}\right)_{2} \mathrm{O}_{7-x 2}$ was obviously higher than that of pure $\operatorname{Sm}_{2} \mathrm{Zr}_{2} \mathrm{O}_{7}$. However, the fracture toughness of each $\left(\mathrm{Sm}_{1-x I} \mathrm{Y}_{x 1}\right)_{2}\left(\mathrm{Zr}_{1-x 2} \mathrm{Y}_{x 2}\right)_{2} \mathrm{O}_{7-x 2}$ ceramic was significantly reduced within $20 \% \mathrm{Y}^{3+}$ ions doping concentration.

(3) In terms of reducing the thermal conductivity of $\mathrm{Sm}_{2} \mathrm{Zr}_{2} \mathrm{O}_{7}$, the substitution of $\mathrm{Y}^{3+}$ ion for $\mathrm{Zr}^{4+}$ was more obvious than the substitution of $\mathrm{Y}^{3+}$ for $\mathrm{Sm}^{3+}$. Thermal conductivity of $\mathrm{Sm}_{2}\left(\mathrm{Zr}_{0.9} \mathrm{Y}_{0.1}\right)_{2} \mathrm{O}_{6.9}$ was $1.315 \mathrm{~W} \cdot \mathrm{m}^{-1} \cdot \mathrm{K}^{-1}$ at $1200{ }^{\circ} \mathrm{C}$, which was about $15 \%$ lower than pure $\mathrm{Sm}_{2} \mathrm{Zr}_{2} \mathrm{O}_{7}$.

(4) Compared with pure $\mathrm{Sm}_{2} \mathrm{Zr}_{2} \mathrm{O}_{7}, \mathrm{Sm}_{2}\left(\mathrm{Zr}_{0.9} \mathrm{Y}_{0.1}\right)_{2} \mathrm{O}_{6.9}$ ceramics exhibited a lower grain growth rate at $1400{ }^{\circ} \mathrm{C}$, and still remained a single pyrochlore crystal phase after sintering for $100 \mathrm{~h}$, indicating that $\mathrm{Sm}_{2}\left(\mathrm{Zr}_{0.9} \mathrm{Y}_{0.1}\right)_{2} \mathrm{O}_{6.9}$ had good high-temperature stability at $1400{ }^{\circ} \mathrm{C}$.

\section{Acknowledgments}

This work was supported by the National Key Research and Development Program of China (Grant No. 2019YFE0107500), Natural Science Foundation of Anhui Province (Grant No. 1908085QE219), Anhui Provincial Key Research and Development Program (Grant No. 201904a05020010).

\section{References}

[1] Qiu S., Liu Y., Guo H., et al. Effect of splat-interface discontinuity on effective thermal conductivity of plasma sprayed thermal barrier coating [J]. Ceramics International, 2020, 46(4): 4824-4831.

[2] Wu S. Xue Z., Ji X., et al. Influence of $\mathrm{Y}_{3} \mathrm{Al}_{5} \mathrm{O}_{12}$ doping on mechanical properties and thermal conductivity of $\mathrm{Sm}_{2} \mathrm{Zr}_{2} \mathrm{O}_{7}-\mathrm{Y}_{3} \mathrm{Al}_{5} \mathrm{O}_{12}$ composite ceramics [J]. Journal of Alloys and Compounds, 2020, 842: 155872.

[3] Darolia R. Thermal barrier coatings technology: critical review, progress update, remaining challenges and prospects [J]. International Materials Reviews, 2013, 58(6): 315-348.

[4] Shi M., Xue Z., Zhang Z., et al. Effect of spraying powder characteristics on mechanical and thermal shock properties of plasma-sprayed YSZ thermal barrier coating [J]. Surface \& Coatings Technology, 2020, 395: 125913.

[5] Vaßen R., Jarligo M., Steinke T., et al. Overview on advanced thermal barrier coatings [J]. Surface \& Coatings Technology, 2010, 205: 938-942.

[6] Sun L., Guo H., Peng H., et al. Phase stability and thermal conductivity of ytterbia and yttria co-doped zirconia [J]. Progress in Natural Science: Materials International, 2013, 23(4): 440-445.

[7] Guo L., Zhang C., Xu L., et al. Effects of TiO2 doping on the defect chemistry and thermo-physical 
properties of $\mathrm{Yb}_{2} \mathrm{O}_{3}$ stabilized $\mathrm{ZrO}_{2}$. [J] Journal of the European Ceramic Society, 2017, 37(13): 4163-4169.

[8] Wu Y., Luo H., Cai C., et al. Comparison of CMAS corrosion and sintering induced microstructural characteristics of APS thermal barrier coatings [J]. Journal of Materials Science \& Technology, 2019, 35(3): 440-447.

[9] Feng J., Xiao B., Wan C., et al. Electronic structure, mechanical properties and thermal conductivity of $\mathrm{Ln}_{2} \mathrm{Zr}_{2} \mathrm{O}_{7}(\mathrm{Ln}=\mathrm{La}, \mathrm{Pr}, \mathrm{Nd}, \mathrm{Sm}, \mathrm{Eu}$ and Gd) pyrochlore [J]. Acta Materialia, 2014, 72(4): 263-265.

[10] Wu H. X., Ma Z., Liu L., et al. Thermal cycling behavior and bonding strength of single-ceramic-layer $\mathrm{Sm}_{2} \mathrm{Zr}_{2} \mathrm{O}_{7}$ and double-ceramic-layer $\mathrm{Sm}_{2} \mathrm{Zr}_{2} \mathrm{O}_{7} / 8 \mathrm{YSZ}$ thermal barrier coatings deposited by atmospheric plasma spraying [J]. Ceramics International, 2016, 42: 12922-12927.

[11] Wang Y., Yang F., Xiao P. Glass-like thermal conductivities in $\left(\operatorname{La}_{1-x 1} \mathrm{Y}_{x 1}\right)_{2}\left(\mathrm{Zr}_{1-x 2} \mathrm{Y}_{x 2}\right) 2 \mathrm{O}_{7-x 2}(x=x 1+x 2,0 \leq \mathrm{x} \leqslant$ 1.0) solid solutions [J]. Acta Materialia, 2012, 60: 7024-7033.

[12] Zhang H., Sun K., Xu Q., et al. Thermal Conductivity of ( $\left.\mathrm{Sm}_{1-x} \mathrm{Laa}_{x}\right)_{2} \mathrm{Zr}_{2} \mathrm{O}_{7}(x=0,0.25,0.5,0.75$ and1) Oxides for Advanced Thermal Barrier Coatings [J]. Journal of Rare Earths, 2009, 27(2): 222-226.

[13] Guo L., Zhang Y., Zhao X., et al. Thermal expansion and fracture toughness of $\left(\mathrm{RE}_{0.9} \mathrm{Sc}_{0.1}\right)_{2} \mathrm{Zr}_{2} \mathrm{O}_{7}(\mathrm{RE}=\mathrm{La}$, Sm, Dy, Er) ceramics [J]. Ceramics International, 2016, 42: 583-588.

[14] Xue Z., Ma Y., Guo H. The influence of Gd doping on thermophysical properties, elasticity modulus and phase stability of garnet-type $\left(\mathrm{Y}_{1-x} \mathrm{Gd}_{x}\right)_{3} \mathrm{Al}_{5} \mathrm{O}_{12}$ ceramics [J]. Journal of the European Ceramic Society, 2017, 37: 4171-4177.

[15] Wang Y., Xiao P. The phase stability and toughening effect of 3Y-TZP dispersed in the lanthanum zirconate ceramics [J]. Materials Science \& Engineering A, 2014, 604: 34-39.

[16] Guo L., Guo H., Peng H., et al. Thermophysical Properties of $\mathrm{Yb}_{2} \mathrm{O}_{3}$ Doped $\mathrm{Gd}_{2} \mathrm{Zr}_{2} \mathrm{O}_{7}$ and Thermal Cycling Durability of $\left(\mathrm{Gd}_{0.9} \mathrm{Yb}_{0.1}\right)_{2} \mathrm{Zr}_{2} \mathrm{O}_{7} / \mathrm{YSZ}$ Thermal Barrier Coatings [J]. Journal of the European Ceramic Society, 2014, 34(5):1255-1263.

[17] Sun L., Guo H., Peng H., et al. Phase stability and thermal conductivity of ytterbia and yttria Co-doped zirconia [J]. Progress in Natural Science: Materials International, 2013, 23(4): 440-445.

[18] Xue Z., Wu S., Qian L., et al. Influence of Y2O3 and Ta2O5 Co-doping on Microstructure and Thermal Conductivity of Gd2Zr2O7 Ceramics[J]. Journal of Materials Engineering and Performance, 2020, 29(8): $1206-1213$

[19] Scheetz B. E., White W. B. Characterization of anion disorder in zirconate $\mathrm{A}_{2} \mathrm{~B}_{2} \mathrm{O}_{7}$ compounds by Raman Spectroscopy [J]. Journal of the American Ceramic Society, 1979: 468-470.

[20] Lu H., Wang C., Zhang C. Influence of $\mathrm{Ln}^{3+}$ and $\mathrm{B}^{3+}$ ions co-substitution on thermophysical properties of $\mathrm{LnMB}_{11} \mathrm{O}_{19}$-type magnetoplumbite $\mathrm{LaMgAl}_{11} \mathrm{O}_{19}$ for advanced thermal barrier coatings [J]. Journal of the American Ceramic Society, 2013, 96(4): 1063-1066.

[21] Liu Z. G., Ouyang J. H., Zhou Y., et al. Influence of ytterbium-and samarium- oxides codoping on structure 
and thermal conductivity of zirconate ceramics [J]. Journal of the European Ceramic Society, 2009, 29: 647-652.

[22] Bansal N. P., Zhu D. M. Effects of doping on thermal conductivity of pyrochlore oxides for advanced thermal barrier coatings[J]. Materials Science \& Engineering A, 2007, 459: 192-195.

[23] Guo L., Guo H., Gong S. The ordering degree and thermal conductivity in the pyrochlore-type composition systems with a constant cation radius ratio [J]. Materials Letter, 2013, 106: 119-121. 


\section{Figures Captions}

Fig. 1 XRD patterns of $\left(\operatorname{Sm}_{1-x 1} \mathrm{Y}_{x 1}\right)_{2}\left(\mathrm{Zr}_{1-x 2} \mathrm{Y}_{x 2}\right)_{2} \mathrm{O}_{7-x 2}$ ceramics with different lattice positions replaced by $\mathrm{Y}^{3+}$ ions.

a). $x 1=x 2=0, b) \cdot x 1=0.1, \mathrm{c}) \cdot x 1=0.2, \mathrm{~d}) \cdot x 2=0.1, \mathrm{e}) \cdot x 2=0.2$

Fig. 2 XRD patterns (between $28^{\circ}$ and $\left.31^{\circ}\right)$ and lattice constants of $\left(\mathrm{Sm}_{1-x 1} \mathrm{Y}_{x 1}\right)_{2}\left(\mathrm{Zr}_{1-x 2} \mathrm{Y}_{x 2}\right)_{2} \mathrm{O}_{7-x 2}$ ceramics with different lattice positions replaced by $\mathrm{Y}^{3+}$ ions

a). $x 1=x 2=0, \mathrm{~b}) \cdot x 1=0.1, \mathrm{c}) \cdot x 1=0.2, \mathrm{~d}) \cdot x 2=0.1, \mathrm{e}) \cdot x 2=0.2$

Fig. 3 Raman spectrum of $\left(\mathrm{Sm}_{1-x 1} \mathrm{Y}_{x 1}\right)_{2}\left(\mathrm{Zr}_{1-x 2} \mathrm{Y}_{x 2}\right)_{2} \mathrm{O}_{7-x 2}$ ceramics
a). $x_{1}=x_{2}=0$;
b). $x_{1}=0.1, x_{2}=0$;
c). $x_{1}=0.2, x_{2}=0$;
d). $x_{1}=0, x_{2}=0.1$;
e). $x_{1}=0, \quad x_{2}=0.2$

Fig. 4 Surface SEM images of $\left(\mathrm{Sm}_{1-x 1} \mathrm{Y}_{x 1}\right)_{2}\left(\mathrm{Zr}_{1-x 2} \mathrm{Y}_{x 2}\right)_{2} \mathrm{O}_{7-x 2}$ ceramics with different lattice positions replaced by $\mathrm{Y}^{3+}$ ions
a). $x_{1}=x_{2}=0$;
b). $x_{1}=0.1, x_{2}=0$;
c). $x_{1}=0.2, x_{2}=0$;
d). $x_{1}=0, \quad x_{2}=0.1$;
e). $x_{1}=0, x_{2}=0.2$

Fig. 5 Specific heat capacities of $\left(\mathrm{Sm}_{1-x 1} \mathrm{Y}_{x 1}\right)_{2}\left(\mathrm{Zr}_{1-x 2} \mathrm{Y}_{x 2}\right)_{2} \mathrm{O}_{7-x 2}$ ceramics
a). $x_{1}=x_{2}=0$;
b). $x_{1}=0.1, x_{2}=0$;
c). $x_{1}=0.2, x_{2}=0$;
d). $x_{1}=0, x_{2}=0.1$;
e). $x_{1}=0, \quad x_{2}=0.2$

Fig. 6 Thermal diffusivities of $\left(\operatorname{Sm}_{1-x l} \mathrm{Y}_{x 1}\right)_{2}\left(\mathrm{Zr}_{1-x 2} \mathrm{Y}_{x 2}\right)_{2} \mathrm{O}_{7-x 2}$ ceramics
a). $x_{1}=x_{2}=0$;
b). $x_{1}=0.1, x_{2}=0$;
c). $x_{1}=0.2, x_{2}=0$;
d). $x_{1}=0, \quad x_{2}=0.1$;
e). $x_{1}=0, \quad x_{2}=0.2$

Fig. 7 Thermal conductivities of $\left(\mathrm{Sm}_{1-x 1} \mathrm{Y}_{x 1}\right)_{2}\left(\mathrm{Zr}_{1-x 2} \mathrm{Y}_{x 2}\right)_{2} \mathrm{O}_{7-x 2}$ ceramics
a). $x_{1}=x_{2}=0$;
b). $x_{1}=0.1, x_{2}=0$;
c). $x_{1}=0.2, x_{2}=0$;
d). $x_{1}=0, \quad x_{2}=0.1$;
e). $x_{1}=0, \quad x_{2}=0.2$

Fig. 8 Microstructure of $\mathrm{Sm}_{2}\left(\mathrm{Zr}_{0.9} \mathrm{Y}_{0.1}\right)_{2} \mathrm{O}_{6.9}$ ceramic sintered at $1400{ }^{\circ} \mathrm{C}$ for different times

Fig. 9 The average grain area of modified $\mathrm{Sm}_{2} \mathrm{Zr}_{2} \mathrm{O}_{7}$ ceramics as a function of sintering time

Fig. $10 \mathrm{XRD}$ patterns of $\mathrm{Sm}_{2}\left(\mathrm{Zr}_{0.9} \mathrm{Y}_{0.1}\right)_{2} \mathrm{O}_{6.9}$ ceramic sintered at $1400{ }^{\circ} \mathrm{C}$ for different times

\section{Tables Captions}

Table 1 Mechanical properties of $\left(\mathrm{Sm}_{1-x l} \mathrm{Y}_{x 1}\right)_{2}\left(\mathrm{Zr}_{1-x 2} \mathrm{Y}_{x 2}\right)_{2} \mathrm{O}_{7-x 2}$ ceramics 


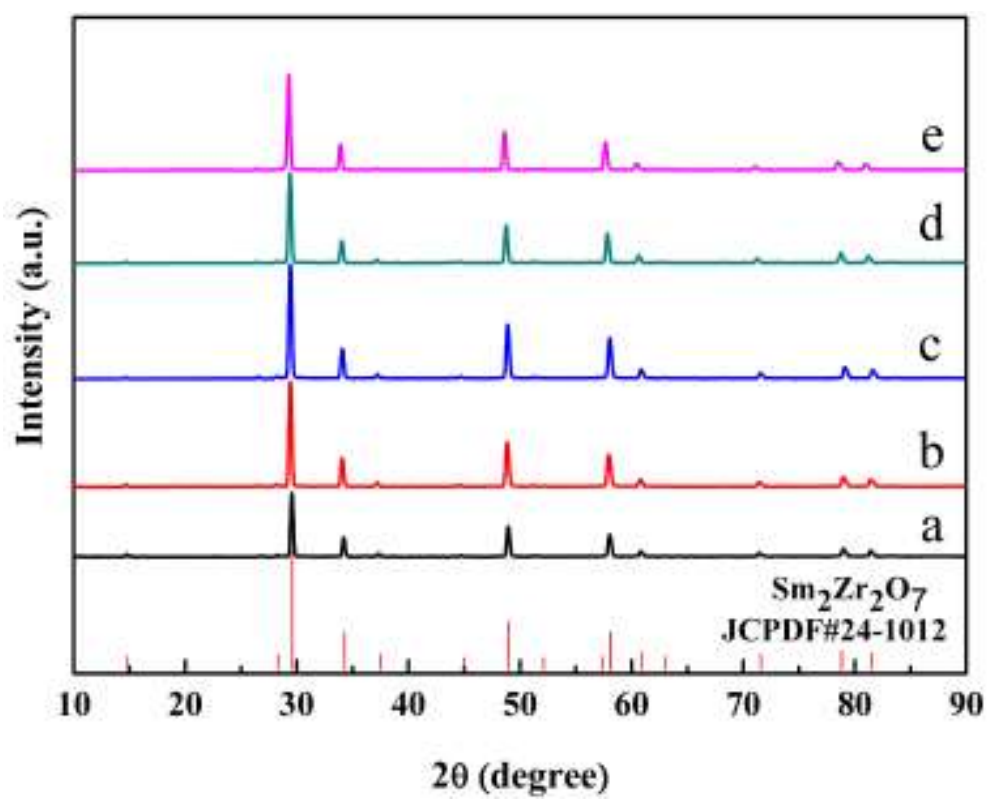

Fig. 1 XRD patterns of $\left(\operatorname{Sm}_{1-x l} \mathrm{Y}_{x 1}\right)_{2}\left(\mathrm{Zr}_{1-x 2} \mathrm{Y}_{x 2}\right)_{2} \mathrm{O}_{7-x 2}$ ceramics with different lattice positions replaced by $\mathrm{Y}^{3+}$ ions.

a). $x 1=x 2=0$, b). $x 1=0.1, \mathrm{c}) \cdot x 1=0.2, \mathrm{~d}) \cdot x 2=0.1, \mathrm{e}) \cdot x 2=0.2$ 

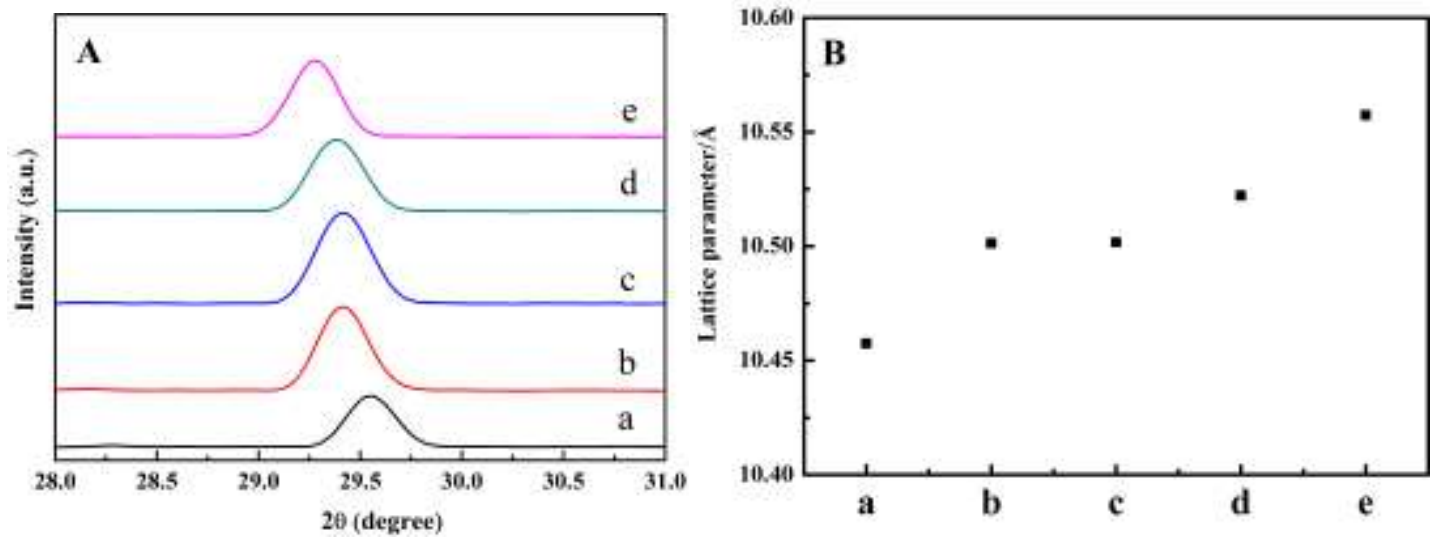

Fig. 2 XRD patterns (between $28^{\circ}$ and $\left.31^{\circ}\right)$ and lattice constants of $\left(\operatorname{Sm}_{1-x l} \mathrm{Y}_{x 1}\right)_{2}\left(\mathrm{Zr}_{1-x 2} \mathrm{Y}_{x 2}\right)_{2} \mathrm{O}_{7-x 2}$ ceramics with different lattice positions replaced by $\mathrm{Y}^{3+}$ ions

a). $x 1=x 2=0, \mathrm{~b}) \cdot x 1=0.1, \mathrm{c}) \cdot x 1=0.2, \mathrm{~d}) \cdot x 2=0.1, \mathrm{e}) \cdot x 2=0.2$ 


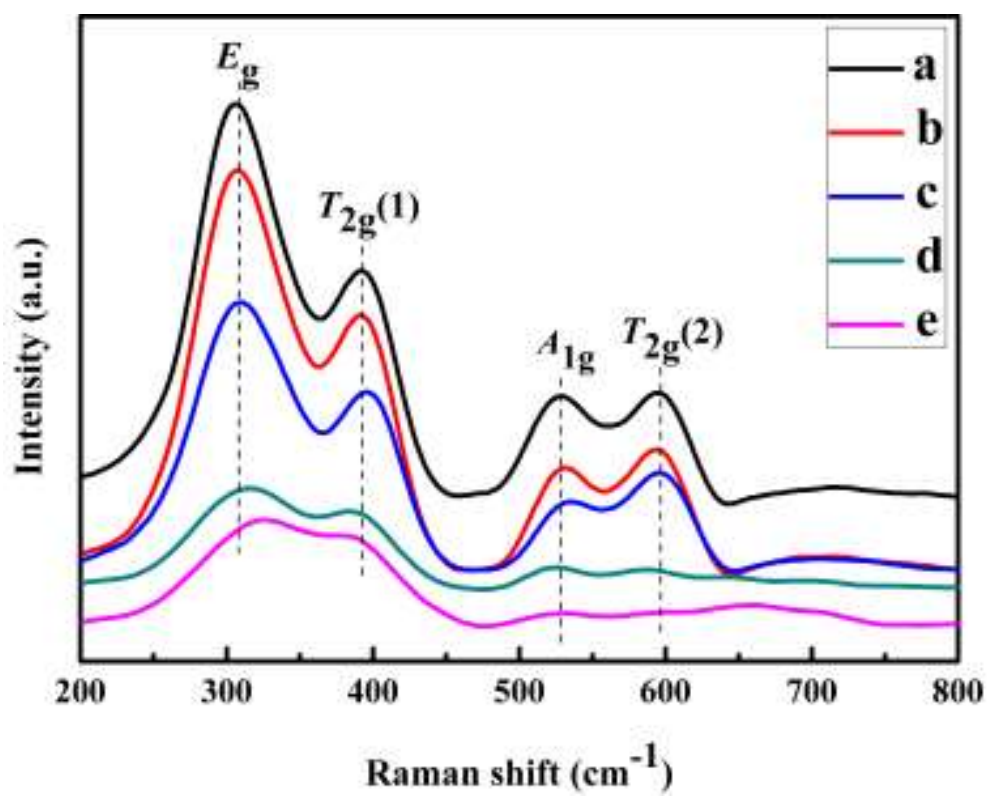

Fig. 3 Raman spectrum of $\left(\mathrm{Sm}_{1-x l} \mathrm{Y}_{x 1}\right)_{2}\left(\mathrm{Zr}_{1-x 2} \mathrm{Y}_{x 2}\right)_{2} \mathrm{O}_{7-x 2}$ ceramics

a). $x_{1}=x_{2}=0 ;$ b). $x_{1}=0.1, x_{2}=0 ;$ c). $x_{1}=0.2, x_{2}=0 ;$ d). $x_{1}=0, x_{2}=0.1 ;$ e). $x_{1}=0, x_{2}=0.2$ 


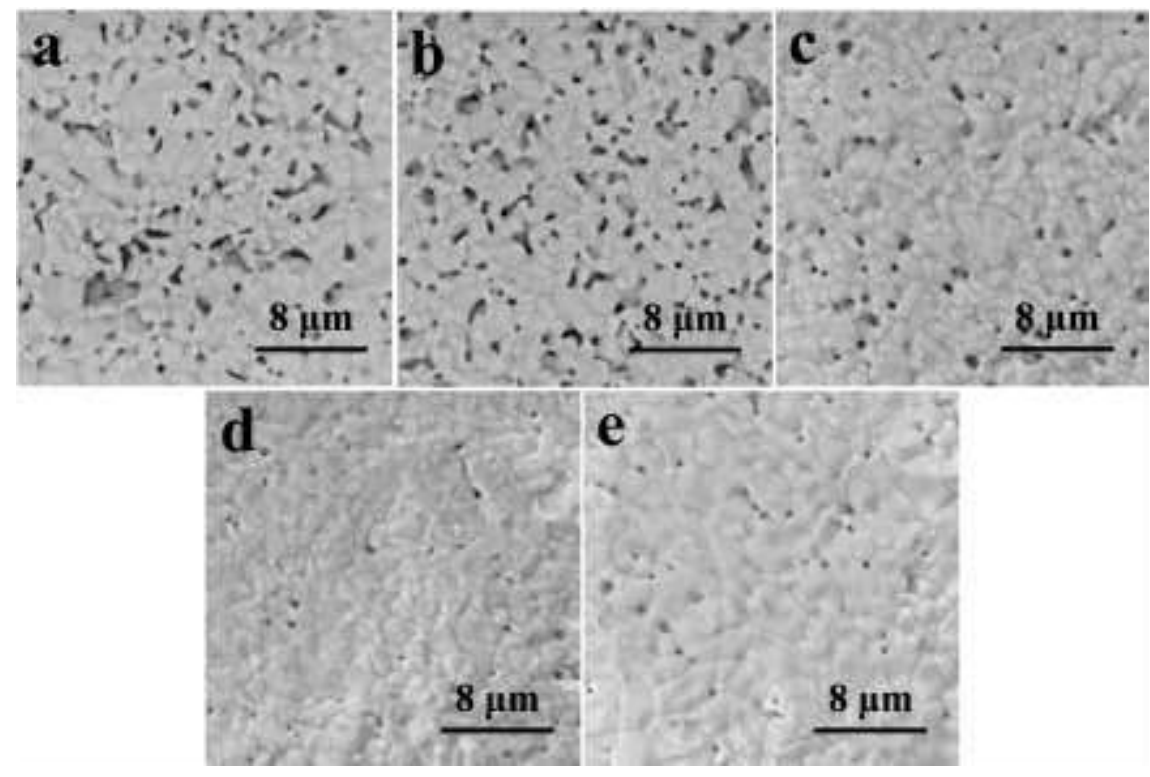

Fig. 4 Surface SEM images of $\left(\operatorname{Sm}_{1-x l} \mathrm{Y}_{x 1}\right)_{2}\left(\mathrm{Zr}_{1-x 2} \mathrm{Y}_{x 2}\right)_{2} \mathrm{O}_{7-x 2}$ ceramics with different lattice positions replaced by $\mathrm{Y}^{3+}$ ions

a). $x_{1}=x_{2}=0 ;$ b). $x_{1}=0.1, x_{2}=0 ;$ c). $x_{1}=0.2, x_{2}=0 ;$ d). $x_{1}=0, x_{2}=0.1 ;$ e). $x_{1}=0, x_{2}=0.2$ 


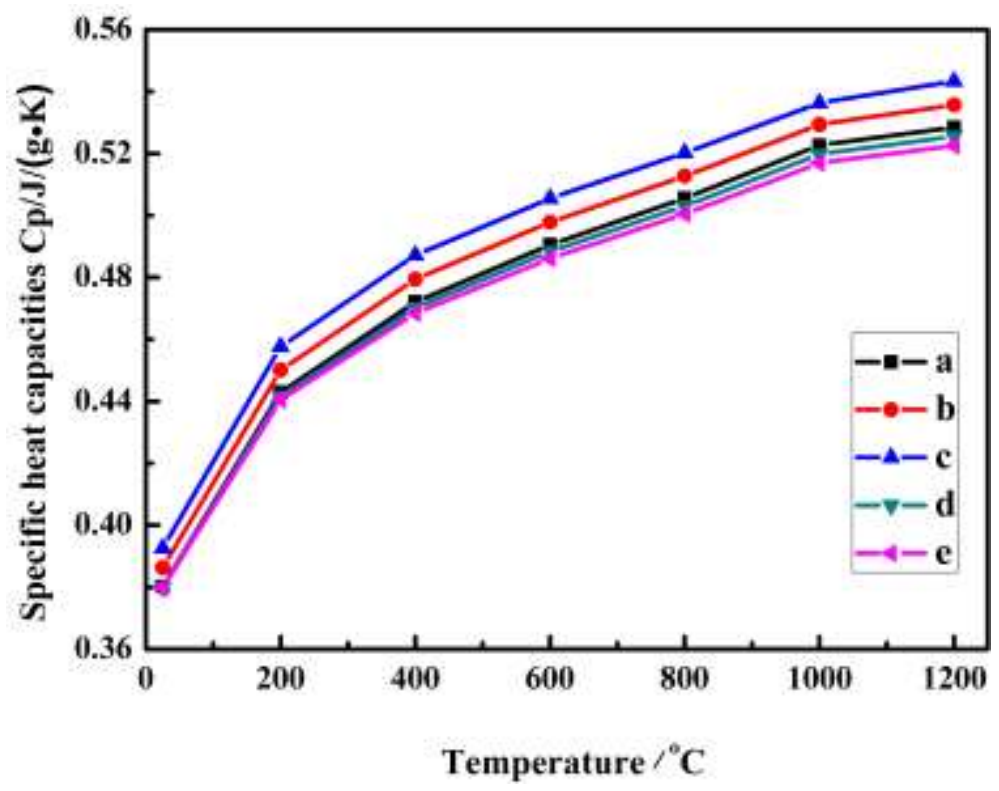

Fig. 5 Specific heat capacities of $\left(\operatorname{Sm}_{1-x l} \mathrm{Y}_{x 1}\right)_{2}\left(\mathrm{Zr}_{1-x 2} \mathrm{Y}_{x 2}\right)_{2} \mathrm{O}_{7-x 2}$ ceramics

a). $x_{1}=x_{2}=0 ;$ b). $x_{1}=0.1, x_{2}=0 ;$ c). $x_{1}=0.2, x_{2}=0 ;$ d). $\left.x_{1}=0, x_{2}=0.1 ; \mathrm{e}\right) \cdot x_{1}=0, x_{2}=0.2$ 


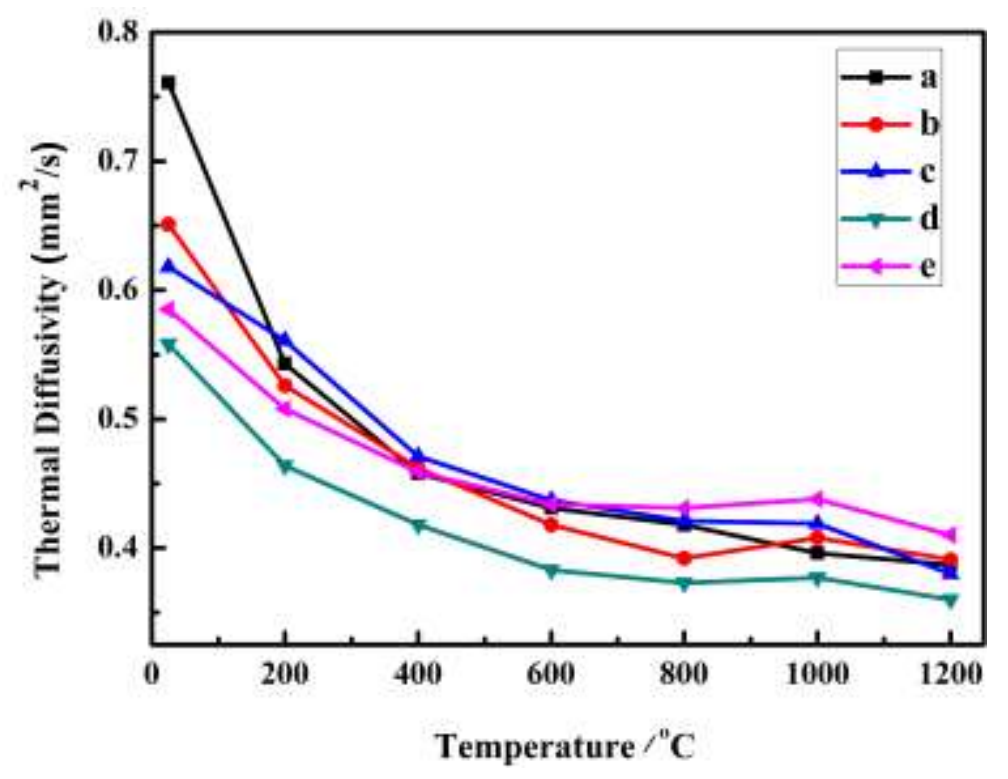

Fig. 6 Thermal diffusivities of $\left(\mathrm{Sm}_{1-x l} \mathrm{Y}_{x 1}\right)_{2}\left(\mathrm{Zr}_{1-x 2} \mathrm{Y}_{x 2}\right)_{2} \mathrm{O}_{7-x 2}$ ceramics a). $x_{1}=x_{2}=0 ;$ b). $x_{1}=0.1, x_{2}=0 ;$ c). $x_{1}=0.2, x_{2}=0 ;$ d). $x_{1}=0, x_{2}=0.1 ;$ e). $x_{1}=0, x_{2}=0.2$ 


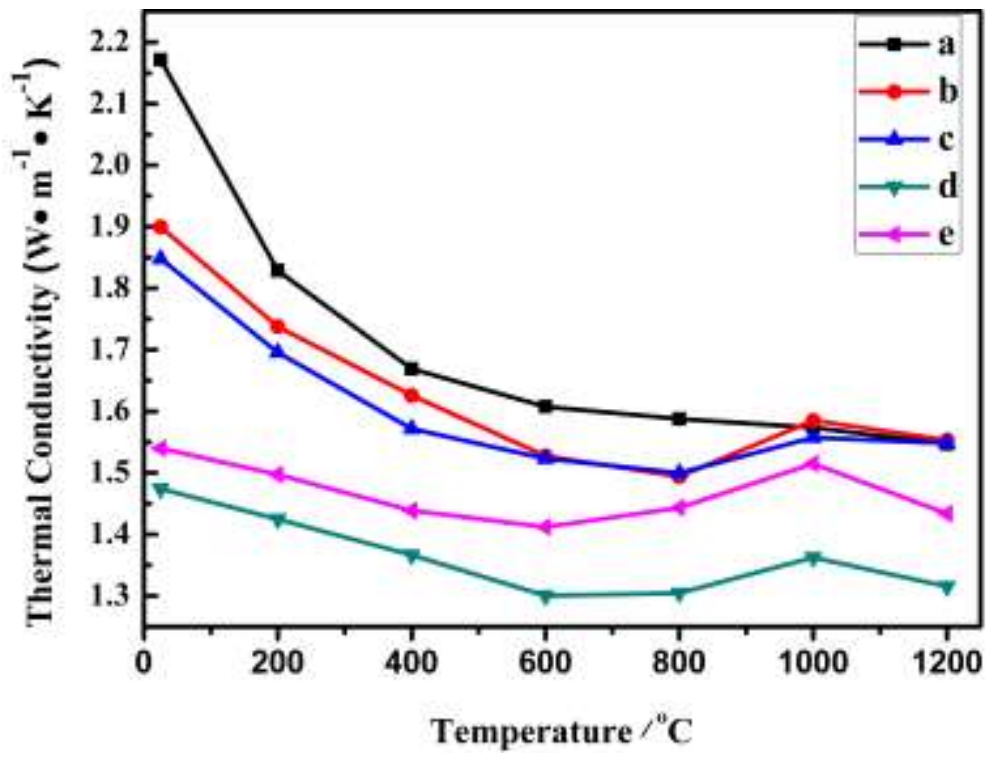

Fig. 7 Thermal conductivities of $\left(\operatorname{Sm}_{1-x I} \mathrm{Y}_{x 1}\right)_{2}\left(\mathrm{Zr}_{1-x 2} \mathrm{Y}_{x 2}\right)_{2} \mathrm{O}_{7-x 2}$ ceramics a). $x_{1}=x_{2}=0 ;$ b). $\left.\left.\left.x_{1}=0.1, x_{2}=0 ; \mathrm{c}\right) \cdot x_{1}=0.2, x_{2}=0 ; \mathrm{d}\right) \cdot x_{1}=0, x_{2}=0.1 ; \mathrm{e}\right) \cdot x_{1}=0, x_{2}=0.2$ 

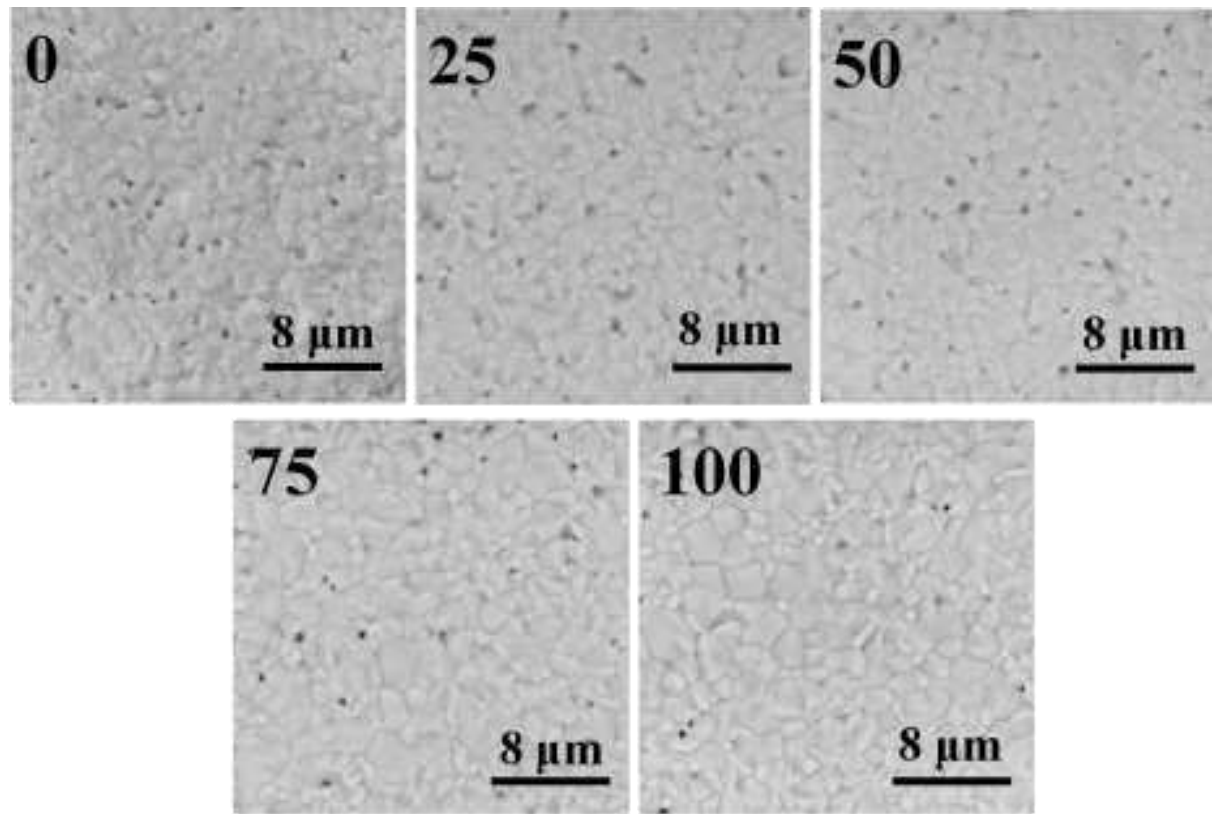

Fig. 8 Microstructure of $\mathrm{Sm}_{2}\left(\mathrm{Zr}_{0.9} \mathrm{Y}_{0.1}\right)_{2} \mathrm{O}_{6.9}$ ceramic sintered at $1400{ }^{\circ} \mathrm{C}$ for different times 


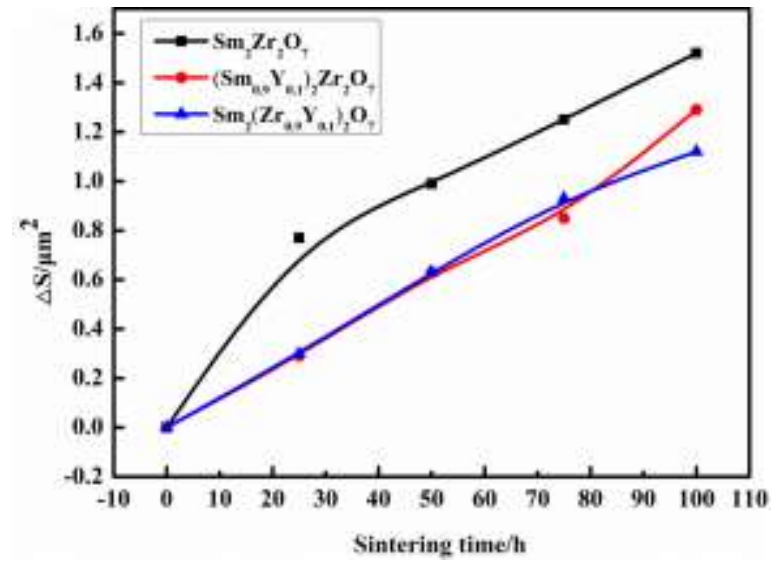

Fig. 9 The average grain area of modified $\mathrm{Sm}_{2} \mathrm{Zr}_{2} \mathrm{O}_{7}$ ceramics as a function of sintering time 


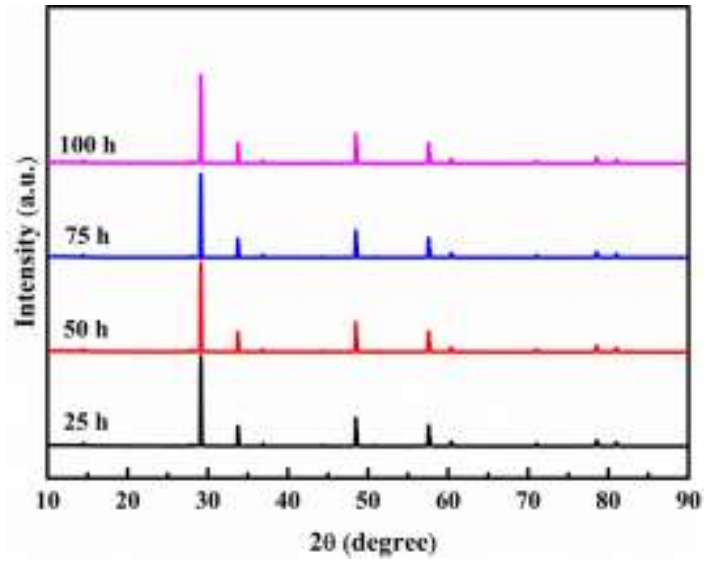

Fig. 10 XRD patterns of $\mathrm{Sm}_{2}\left(\mathrm{Zr}_{0.9} \mathrm{Y}_{0.1}\right)_{2} \mathrm{O}_{6.9}$ ceramic sintered at $1400{ }^{\circ} \mathrm{C}$ for different times 
Figures

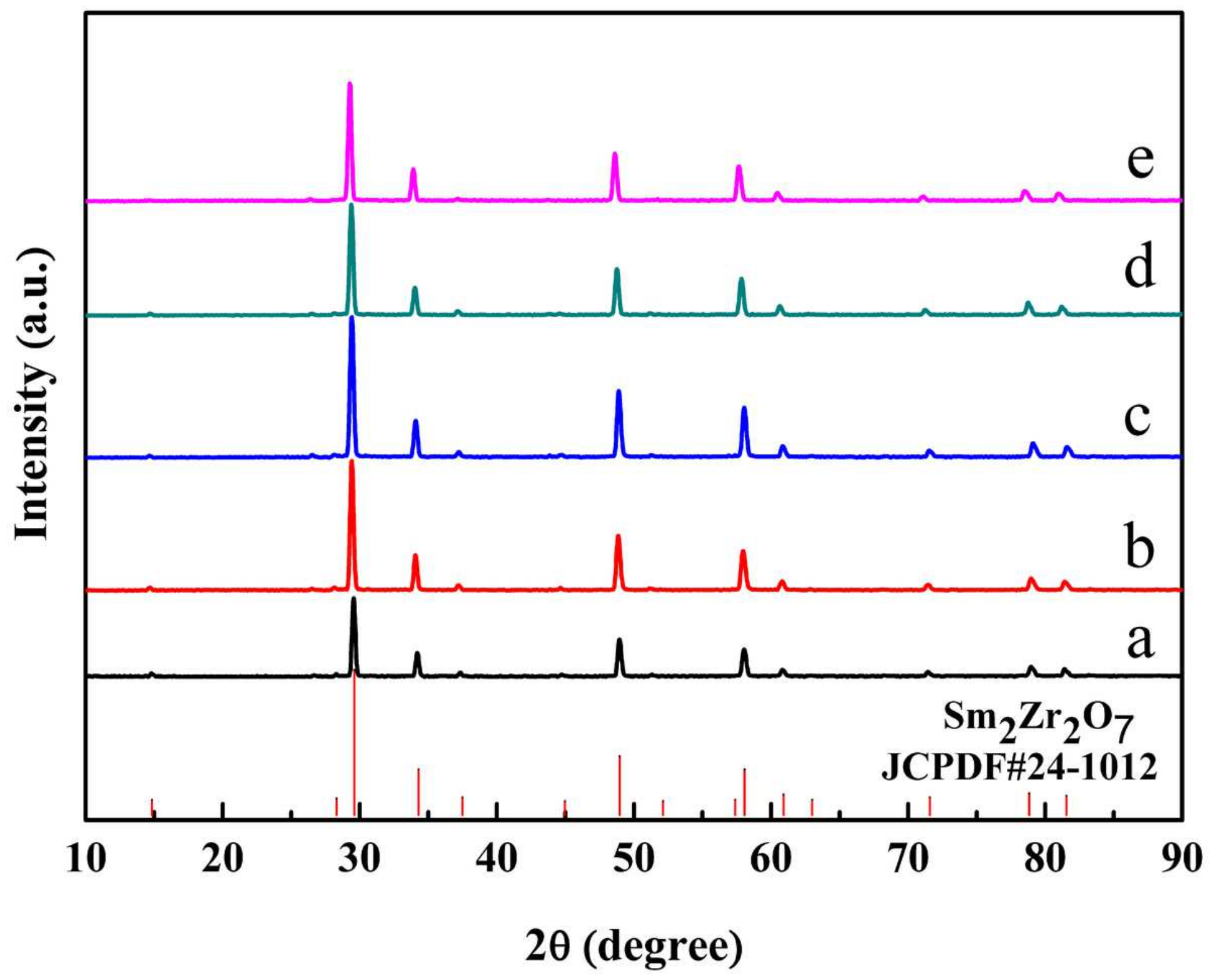

Figure 1

XRD patterns of (Sm1-x1Yx1)2(Zr1-x2Yx2)207-x2 ceramics with different lattice positions replaced by $Y 3+$ ions. a). $x 1=x 2=0, b) \cdot x 1=0.1, c) \cdot x 1=0.2, d) \cdot x 2=0.1, e) \cdot x 2=0.2$ 

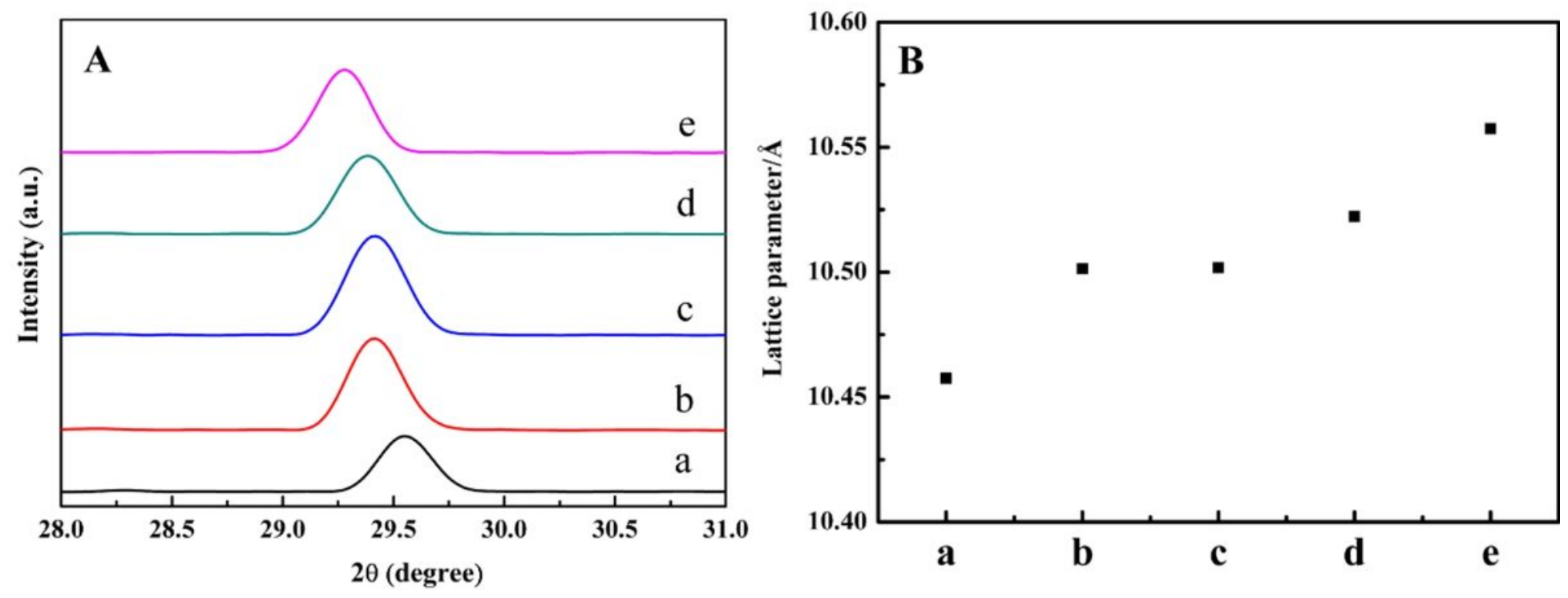

Figure 2

XRD patterns (between $28^{\circ}$ and $\left.31^{\circ}\right)$ and lattice constants of (Sm1-x1YX1)2(Zr1-x2Yx2)2O7-x2 ceramics with different lattice positions replaced by $Y 3+$ ions $a) . x 1=x 2=0, b) . x 1=0.1, c) . x 1=0.2, d) . x 2=0.1, e$ ). $\mathrm{x} 2=0.2$ 


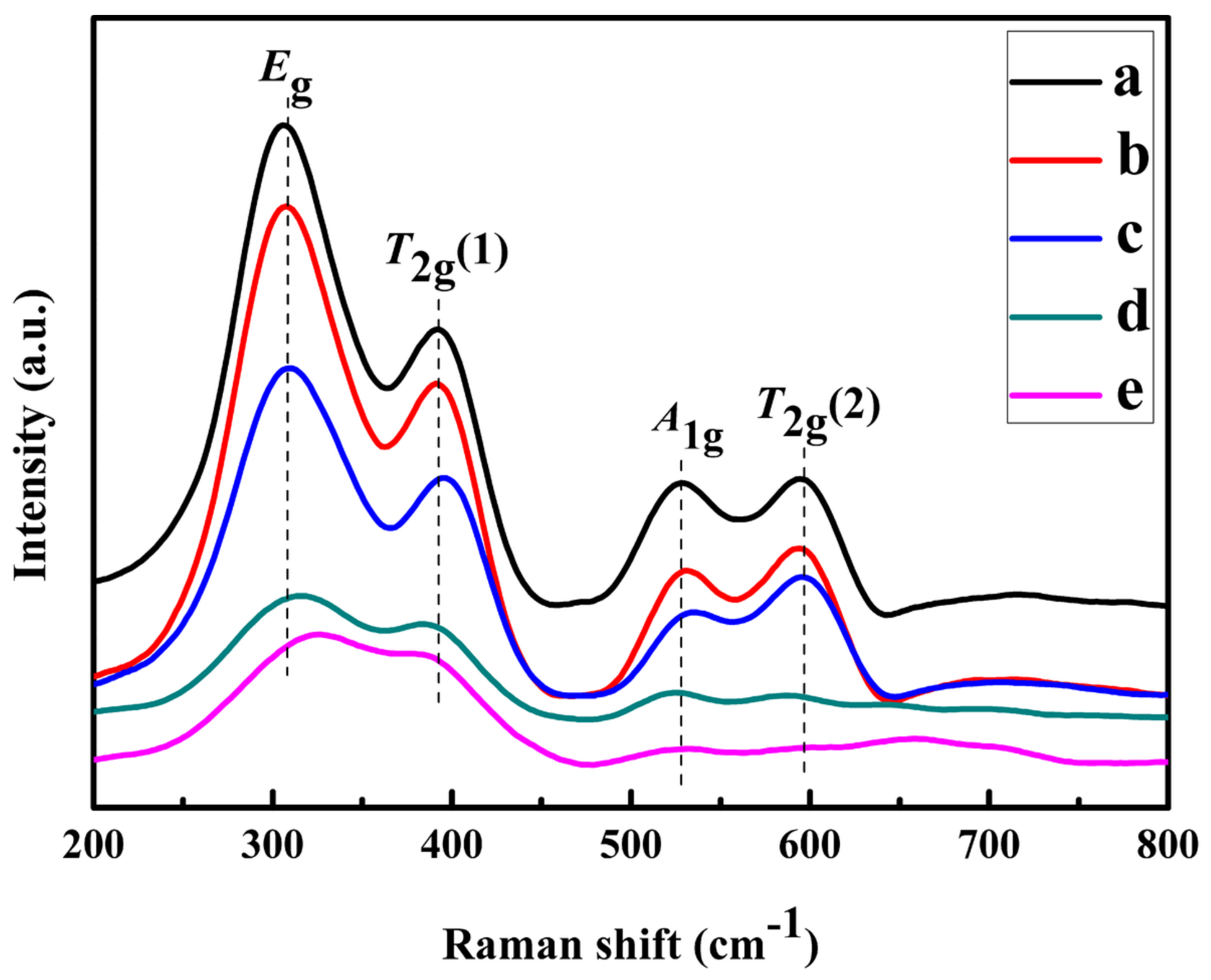

Figure 3

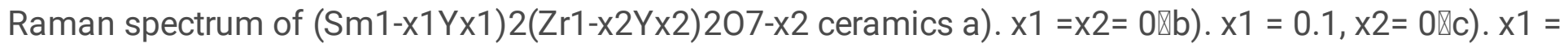
$0.2, x 2=0 \rrbracket d) \cdot x 1=0 \rrbracket \times 2=0.1 \rrbracket e) \cdot x 1=0 \rrbracket \times 2=0.2$ 


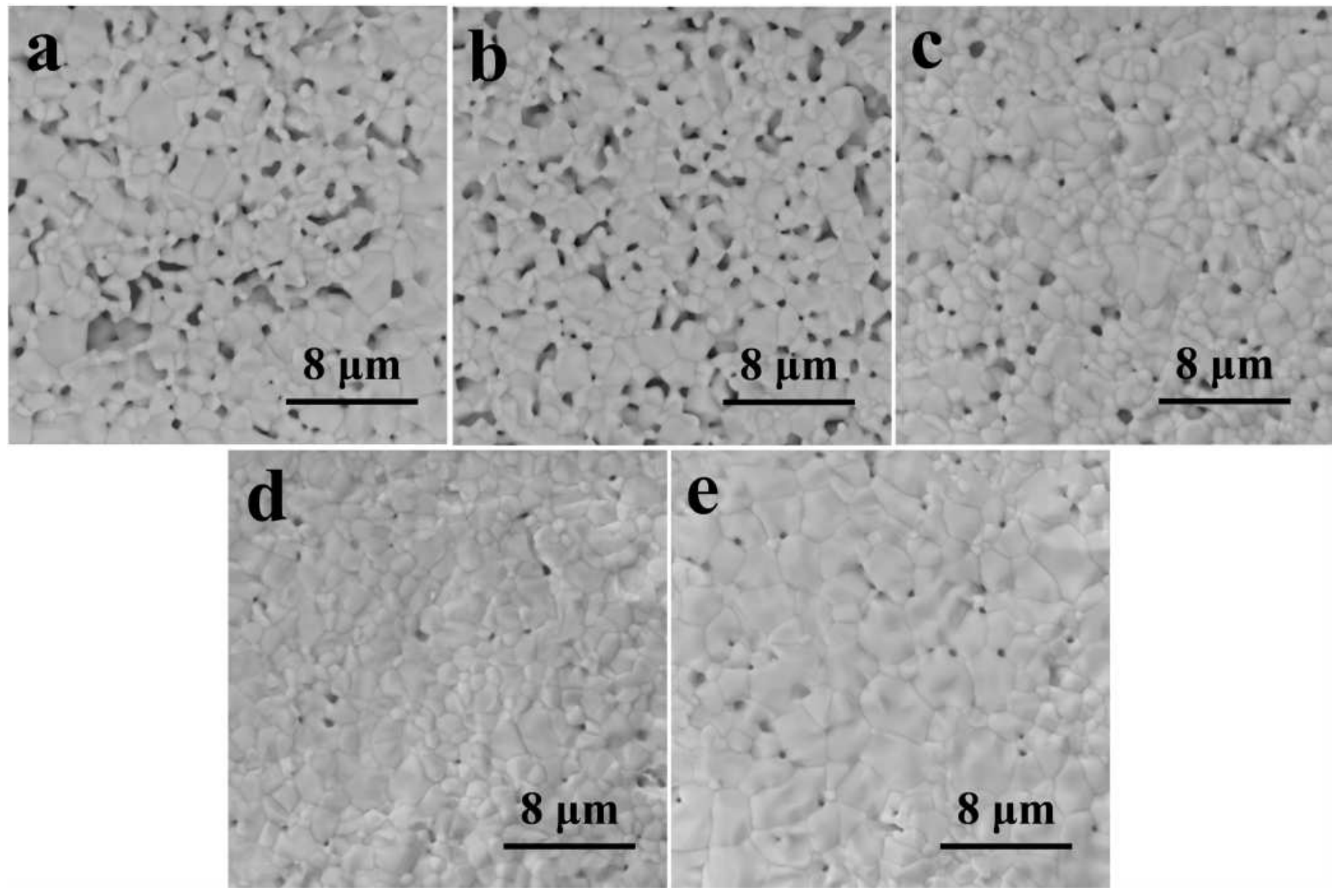

Figure 4

Surface SEM images of (Sm1-x1Yx1)2(Zr1-x2Yx2)207-x2 ceramics with different lattice positions replaced by $Y 3+$ ions a). $x 1=x 2=0 \rrbracket b) . x 1=0.1, x 2=0 \rrbracket c) \cdot x 1=0.2, x 2=0 \rrbracket d) . x 1=0 \rrbracket x 2=0.1 \rrbracket e) . x 1=0 \rrbracket x 2$ $=0.2$ 


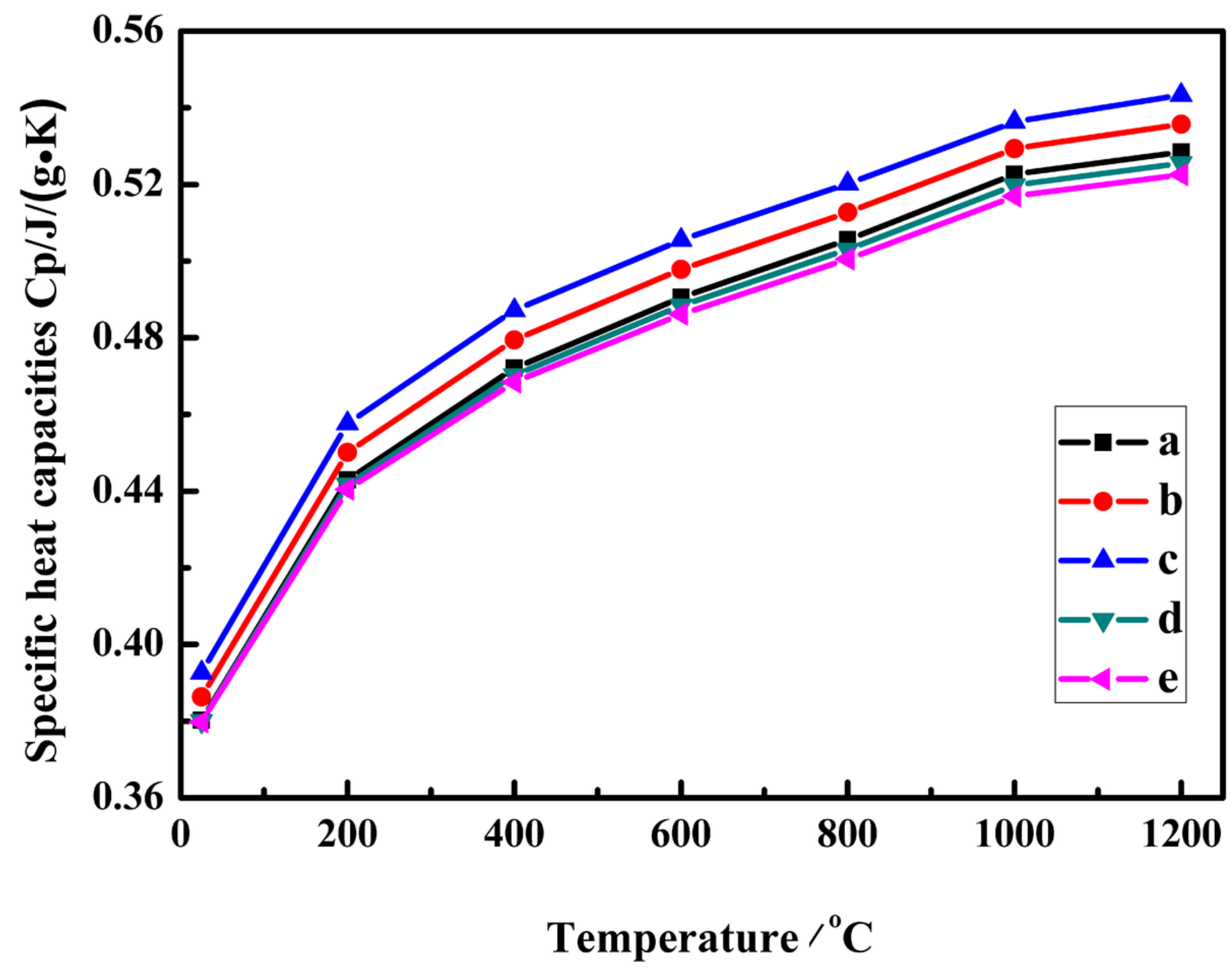

Figure 5

Specific heat capacities of $(S m 1-x 1 Y x 1) 2(Z r 1-x 2 Y x 2) 207-x 2$ ceramics $a) . x 1=x 2=0 \otimes b) . x 1=0.1, x 2=0 \bigotimes$ c). $x 1=0.2, x 2=0 \rrbracket d) \cdot x 1=0 \rrbracket \times 2=0.1 \rrbracket e) \cdot x 1=0 \rrbracket \times 2=0.2$ 


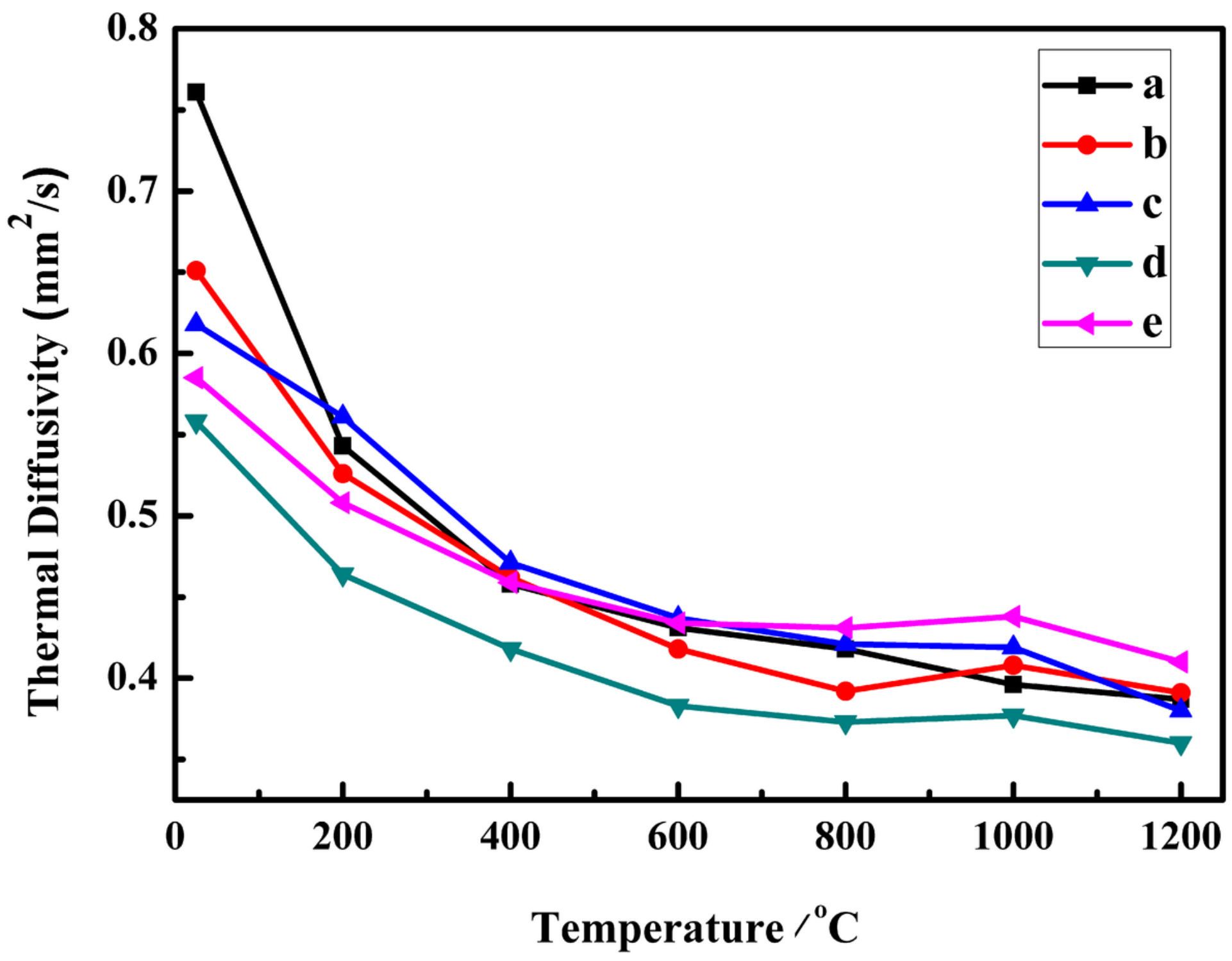

Figure 6

Thermal diffusivities of (Sm1-x1Yx1)2(Zr1-x2Yx2)207-x2 ceramics a). x1 =x2=0邓b). x1 =0.1, x2=0邓c). $x 1=0.2, x 2=0 \rrbracket d) \cdot x 1=0 \rrbracket x 2=0.1 \rrbracket e) \cdot x 1=0 \rrbracket x 2=0.2$ 


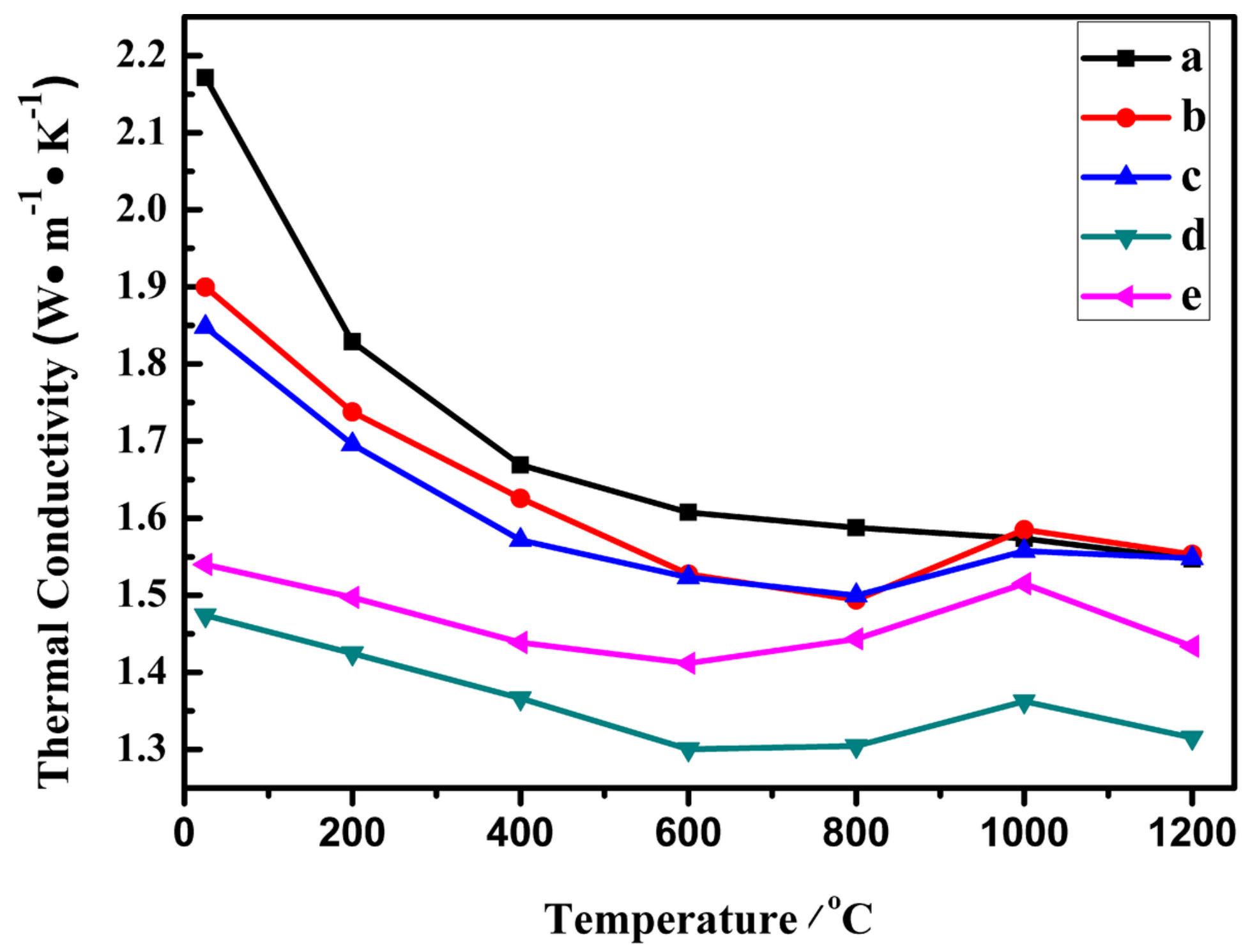

Figure 7

Thermal conductivities of $(S m 1-x 1 Y x 1) 2(Z r 1-x 2 Y x 2) 207-x 2$ ceramics $a) . x 1=x 2=0 \rrbracket b) . x 1=0.1, x 2=0 \rrbracket c)$. $x 1=0.2, x 2=0 \rrbracket d) . x 1=0 \rrbracket x 2=0.1 \rrbracket e) \cdot x 1=0 \rrbracket x 2=0.2$ 

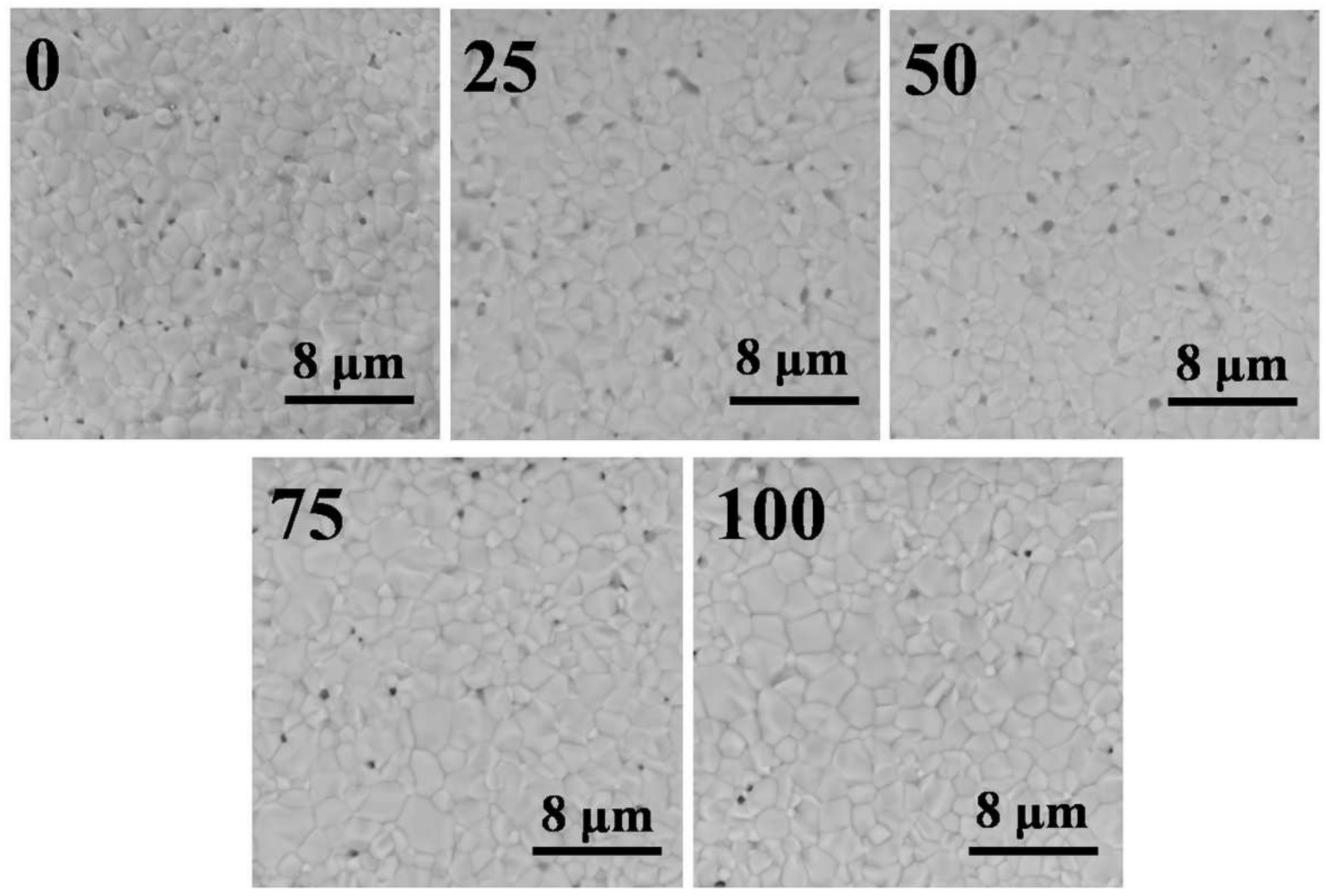

Figure 8

Microstructure of $\mathrm{Sm} 2(\mathrm{Zr} 0.9 \mathrm{Y} 0.1) 206.9$ ceramic sintered at $1400{ }^{\circ} \mathrm{C}$ for different times 


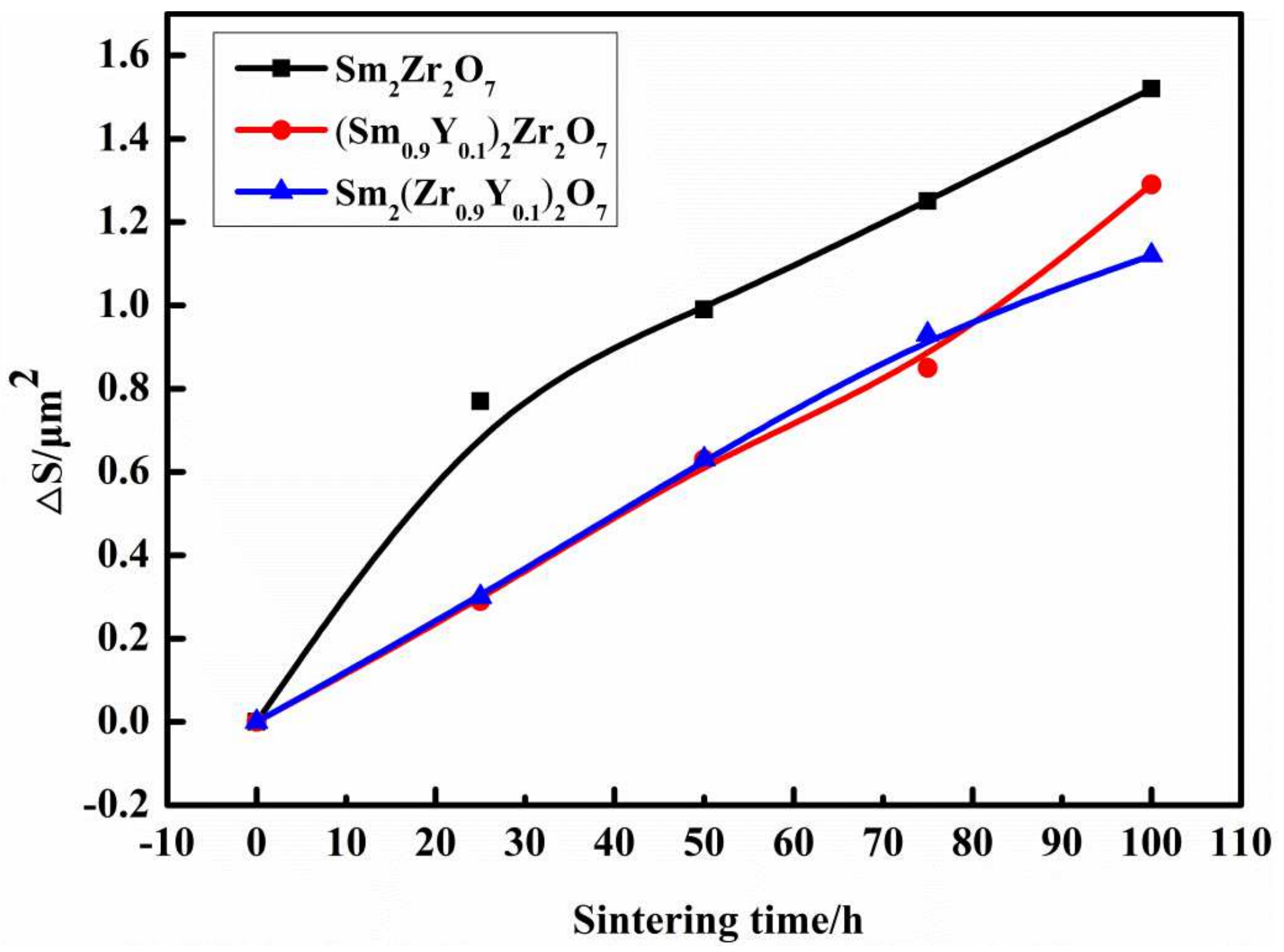

Figure 9

The average grain area of modified Sm2Zr2O7 ceramics as a function of sintering time 


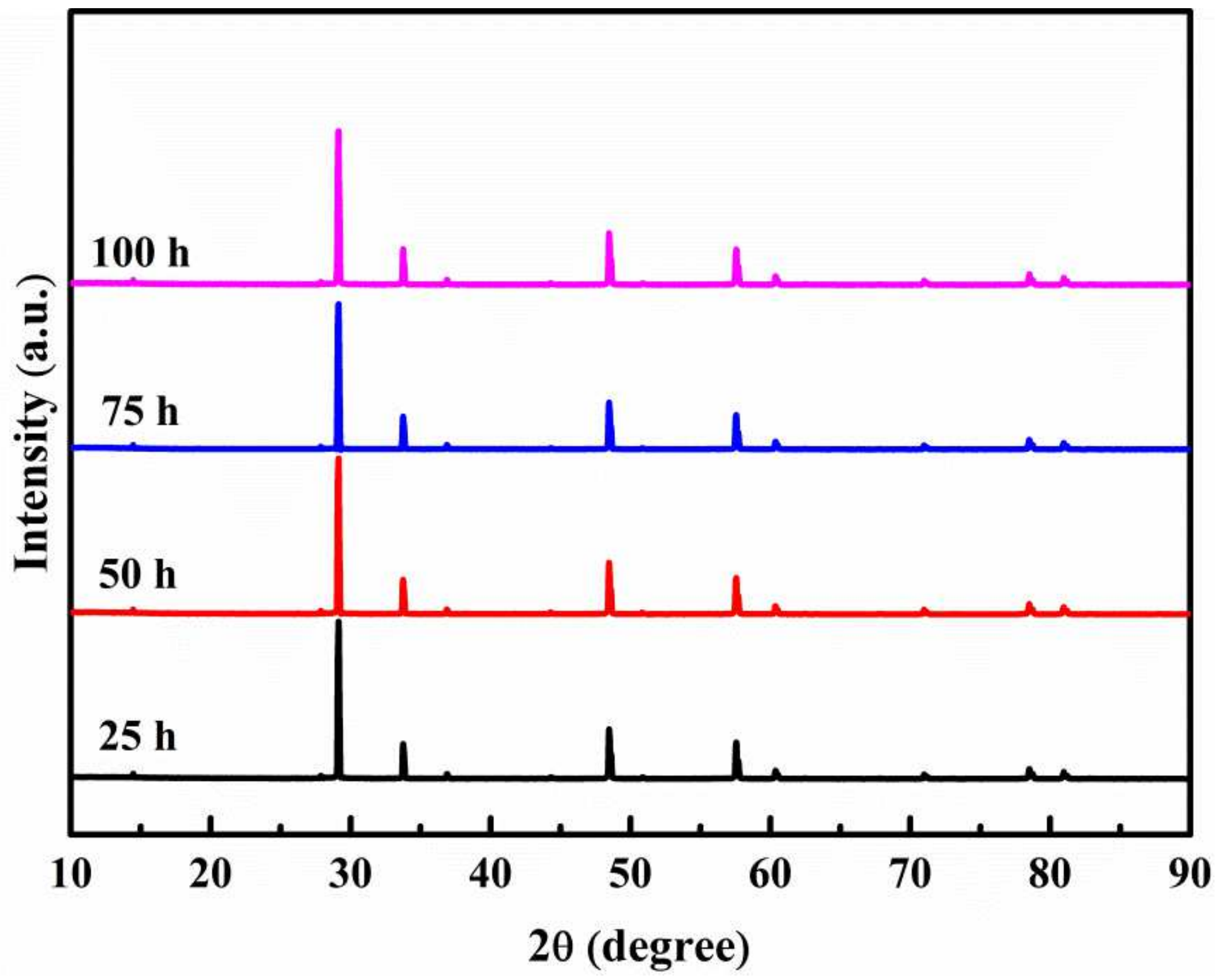

Figure 10

XRD patterns of $\mathrm{Sm} 2(\mathrm{Zr} 0.9 Y 0.1) 206.9$ ceramic sintered at $1400{ }^{\circ} \mathrm{C}$ for different times 